\title{
The Jack Walton Site (41SA135), San Augustine County, Texas
}

Tom Middlebrook

Heritage Research Center, Stephen F. Austin State University

Follow this and additional works at: https://scholarworks.sfasu.edu/ita

Part of the American Material Culture Commons, Archaeological Anthropology Commons, Environmental Studies Commons, Other American Studies Commons, Other Arts and Humanities Commons, Other History of Art, Architecture, and Archaeology Commons, and the United States History Commons

Tell us how this article helped you.

This Article is brought to you for free and open access by the Center for Regional Heritage Research at SFA ScholarWorks. It has been accepted for inclusion in Index of Texas Archaeology: Open Access Gray Literature from the Lone Star State by an authorized editor of SFA ScholarWorks. For more information, please contact cdsscholarworks@sfasu.edu. 


\section{The Jack Walton Site (41SA135), San Augustine County, Texas \\ Creative Commons License \\ (c) $($ ) $(9)$}

This work is licensed under a Creative Commons Attribution-NonCommercial 4.0 International License 


\section{The Jack Walton Site (41SA135), San Augustine County, Texas}

\section{Tom Middlebrook}

\section{INTRODUCTION}

This article describes archaeological excavations I conducted at the Jack Walton site (41SA135) in San Augustine County, Texas, between November 1981 and July 1982, with the assistance of Suzanne Middlebrook and John Hart (see also Middlebrook 1983). During a total of 20 days in the field, $14 \mathrm{~m}^{2}$ were excavated in four areas of the site (Figure 1). The excavated units are designated Areas 1, 2, 3, and 4. The site is located on a high bluff overlooking the Attoyac Bayou. It was apparently wooded until the 1930s, when the timber was clear cut; the present open field has been used for pasture and cultivation of corn since. Although Walton family members have collected surface artifacts from the area for many years, the site has been undisturbed by pothunters and looters.

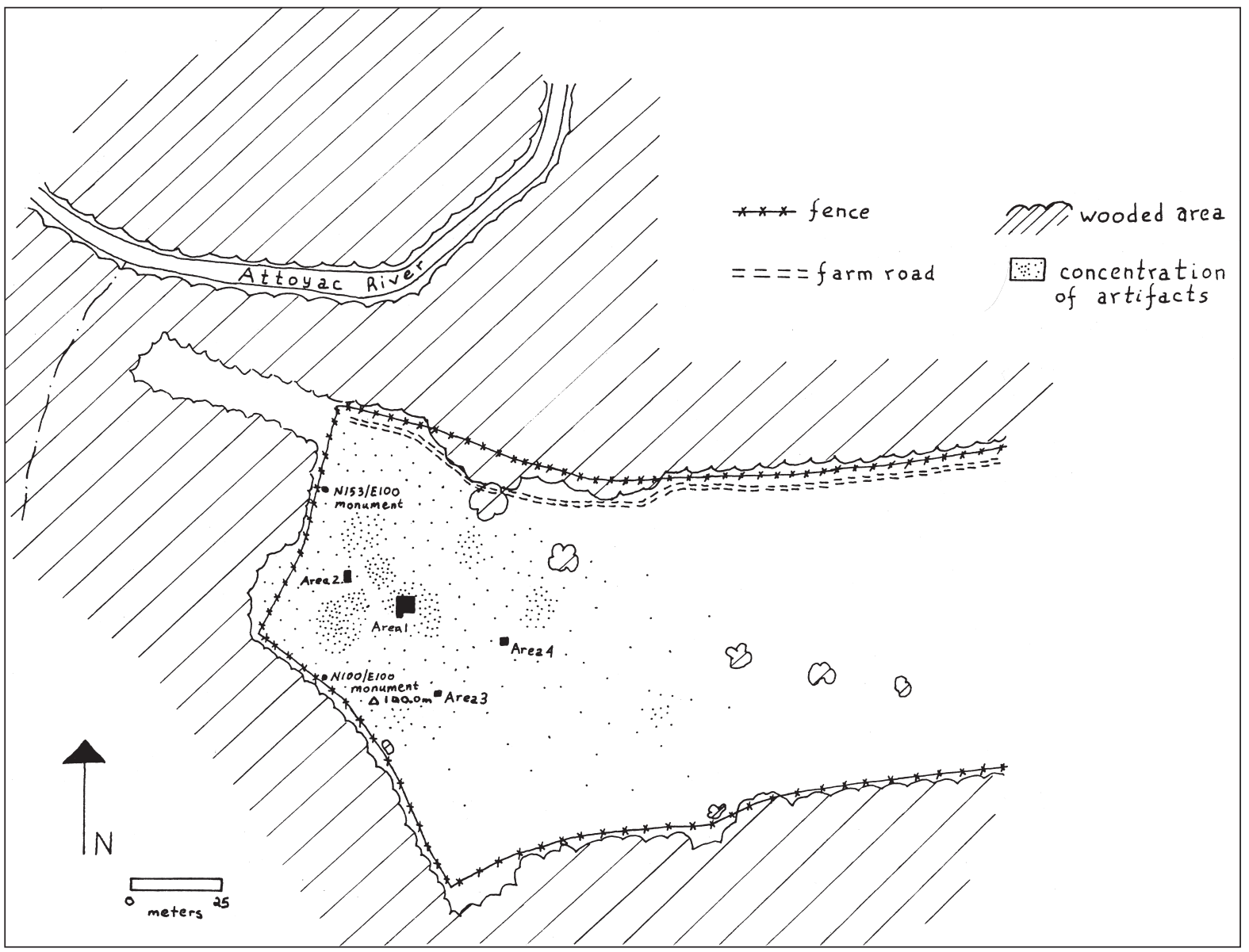

Figure 1. Sketch map of the Jack Walton site, showing the four excavation areas. 
The Walton site was first reported in May 1980 by Dr. James E. Corbin. His site form described a surface collection of "hundreds of Caddoan potsherds, hundreds of lithic flakes, arrowpoints, dartpoints, pitted stones, milling stones, hammerstones, $3 / 4$ grooved axe, fragments of granite porphyry, Frio point of Central Texas flint." I became aware of the site in June 1981 through information provided by Mr. Bud Hooper, who had collected projectile points there years ago. After several trips to the site, I became convinced that the site would lend itself well to ongoing dual research goals: (1) to arrive at a thoughtful understanding of the prehistoric peoples inhabiting the site through careful excavation, laboratory analysis, and appropriate environmental study; and (2) to provide adequate field work for the archaeological education and training of the primary investigators.

\section{THE JACK WALTON SITE}

The Walton site is situated on a tongue of a Pleistocene fluvial terrace rising about $15 \mathrm{~m}$ above the eastern floodplain of the Attoyac Bayou, $20 \mathrm{~km}$ west of the city of San Augustine and $2.4 \mathrm{~km}$ north of the Highway 21 crossing (El Camino Real de los Tejas) of the Attoyac. The selection of this bluff by perhaps several groups of aboriginal peoples was undoubtedly influenced by the fact that it is the only high ground near the bayou for several kilometers in both directions (Figure 2). It is located only 50 $m$ south of an eastward projecting meander of the bayou (Figure 3). While the terrace has an overall general incline to the east, the topography is gently rolling. There are many $0.5 \mathrm{~m}$ high rises or small knolls across the site (Figure 4).

From casual surface collections, there is a differential spatial distribution of artifacts across the site. Lithic debitage and dart points are scattered over a ca. $150 \times 300 \mathrm{~m}$ area (ca. 11 acres), but the majority of ceramic sherds are concentrated in a 100 x $100 \mathrm{~m}$ area nearest the bayou. This smaller cluster is also notable for several areas of darkly stained soil in the otherwise light-colored sandy loam soil.

In Areas 1-4, the soil A-horizon is quite shallow, rarely more than $20 \mathrm{~cm}$ in depth. The typical plow zone (Ap horizon) in the midden areas (Areas 1, 2, and 4) is a dark brown (7.5YR 4/4) friable sandy loam with abundant gravel-sized particles and many fine roots. In addition to the ceramic and lithic artifacts, bits of charcoal and flecks of bone speckle the soil. Only in Area 4 was undisturbed A-horizon midden present beneath the plow zone (Figure 5). Numerous recent and fossil gopher runs are evident in the lower part of the A-horizon, often packed with lithics and ceramics from rodent backfilling. The B-horizon is a reddish-yellow (7.5YR 6/6) to yellowish-brown (10YR 5/6) mottled, and moderately friable to blocky, sandy clay with abundant gravel (ferromanganese or other iron-containing concretions). Because of their darker color from midden staining, aboriginal cultural features are most easily noted when levels within the B-horizon are troweled. However, the many gopher runs and old root stains that are present are easily confused with features, and careful excavations are required to distinguish between them

\section{METHODS}

A metric coordinate system was used for excavations at the Jack Walton site, established by placing a N100/E100 monument (with an elevation of $100.0 \mathrm{~m}$ ) near the southwest margin of the site and along a fence line. At this spot a $4 \times 6 \times 12$ inch cinderblock was firmly buried in the ground, with its $4 \times 6$ inch surface exposed flush with the ground surface. An additional cinderblock is buried at N153/ E100 to mark a true north-south line.

A systematic surface collection of artifacts in 10 $\mathrm{x} 10 \mathrm{~m}$ units was to be done prior to initiating the excavations; however, the site was covered with tall grass, leaving little topsoil exposed during the field sessions. Occasional projectile points and decorated sherds have been collected from gopher mounds, but more formal surface collection must await future disking of the field.

The initial area for excavation-a $3 \times 3 \mathrm{~m}$ unit at N118/E121 - was selected for its apparent central location in the site and an abundance of surface artifacts (Area 1). Subsequent areas were chosen to sample other midden deposits (Areas 2 and 4) and places with light colored soil (Area 3).

Each 1 x $1 \mathrm{~m}$ unit was excavated in $10 \mathrm{~cm}$ levels. Because of the shallowness of the A-horizon, 11 of the 14 units were excavated only to Level II (20 $\mathrm{cm} \mathrm{bs}$ ); the remaining three units were excavated to Level III $(30 \mathrm{~cm} \mathrm{bs})$. In later phases of the excavations, soil profiles were drawn of at least one wall of each unit, and Munsell colors were noted for the different soil horizons. At each level, the floor and walls of the units were carefully troweled for the identification of cultural features; plan maps were 


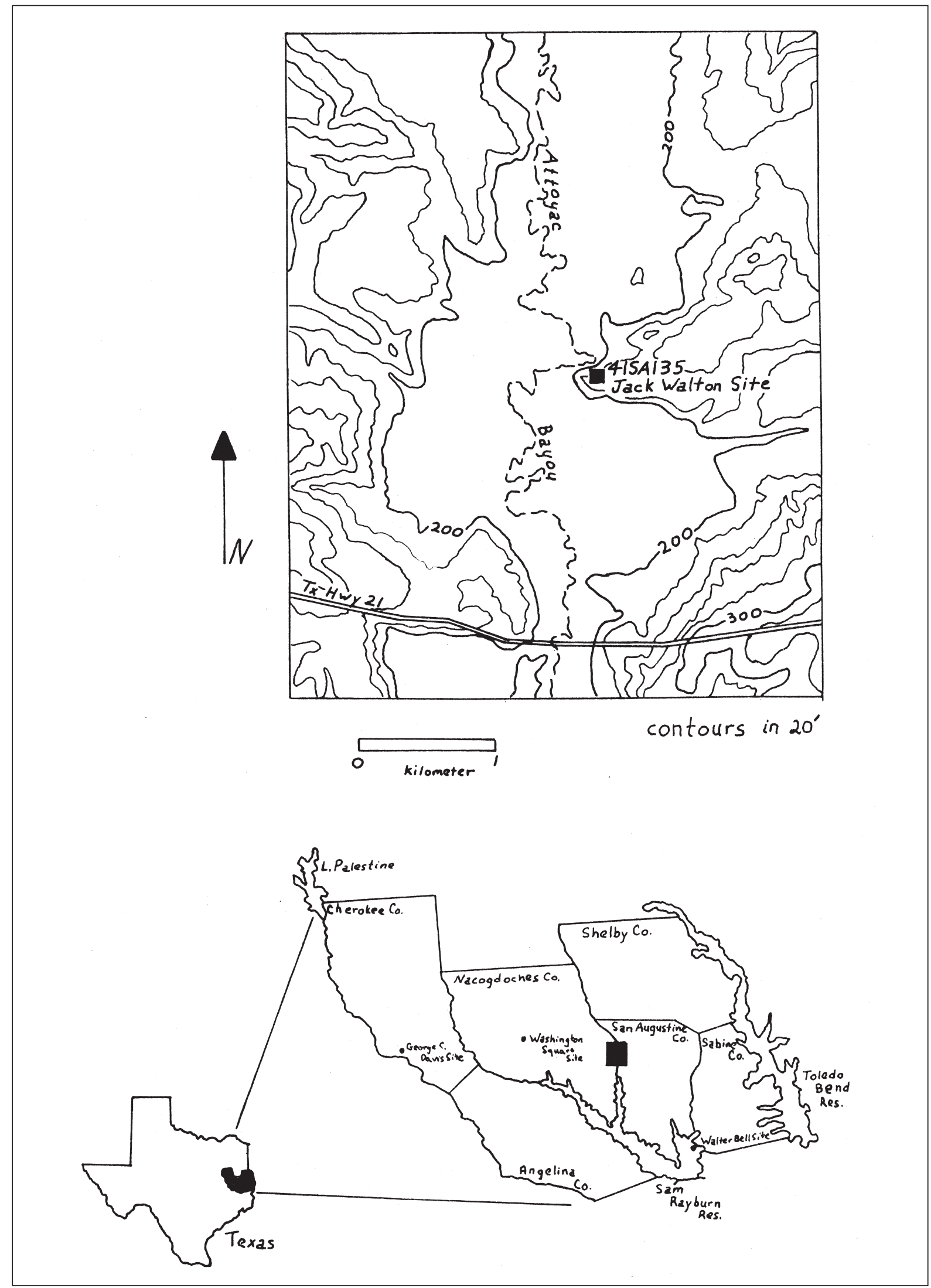

Figure 2. Topographic map of the Jack Walton site and its location within San Augustine County and East Texas. 


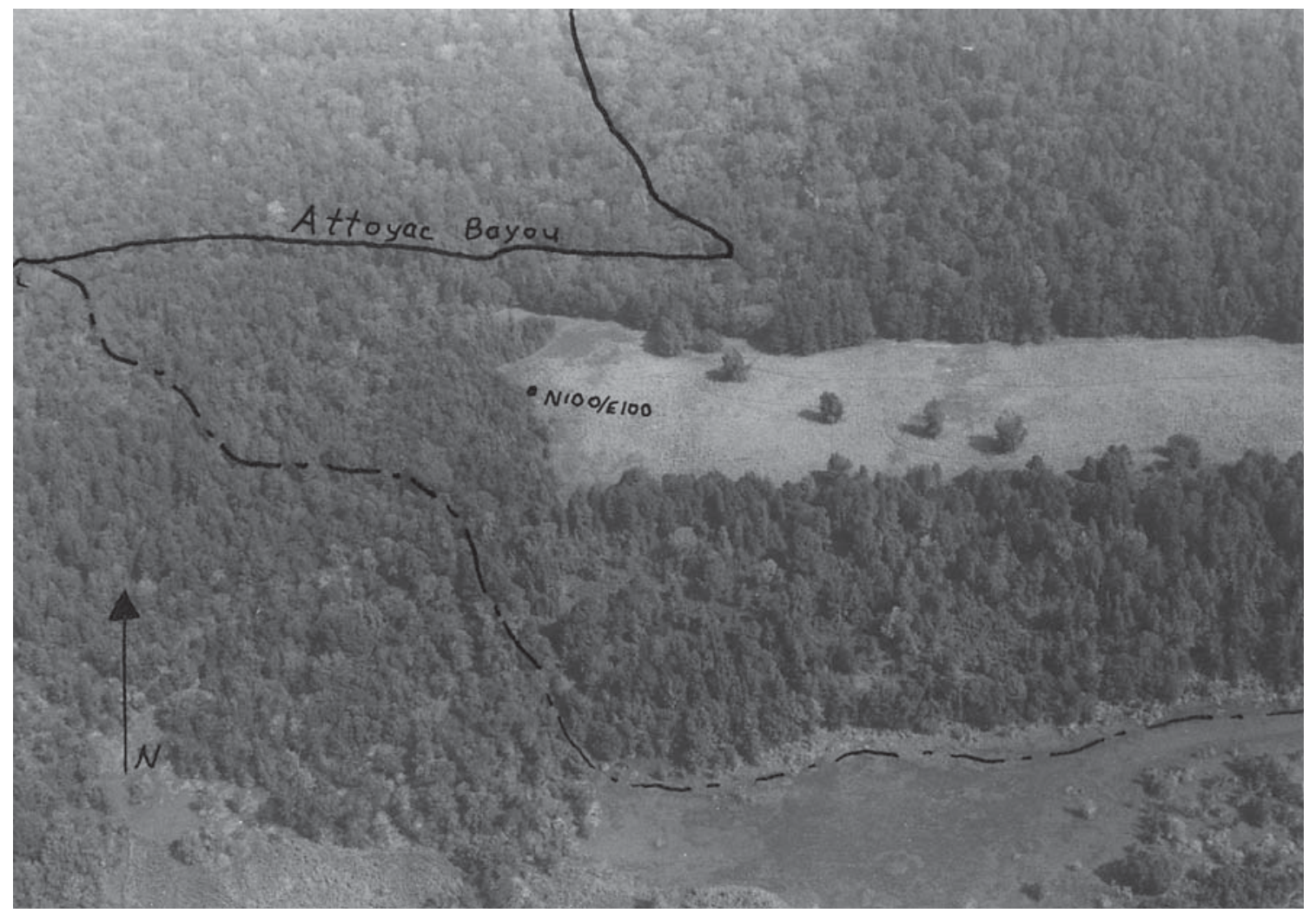

a

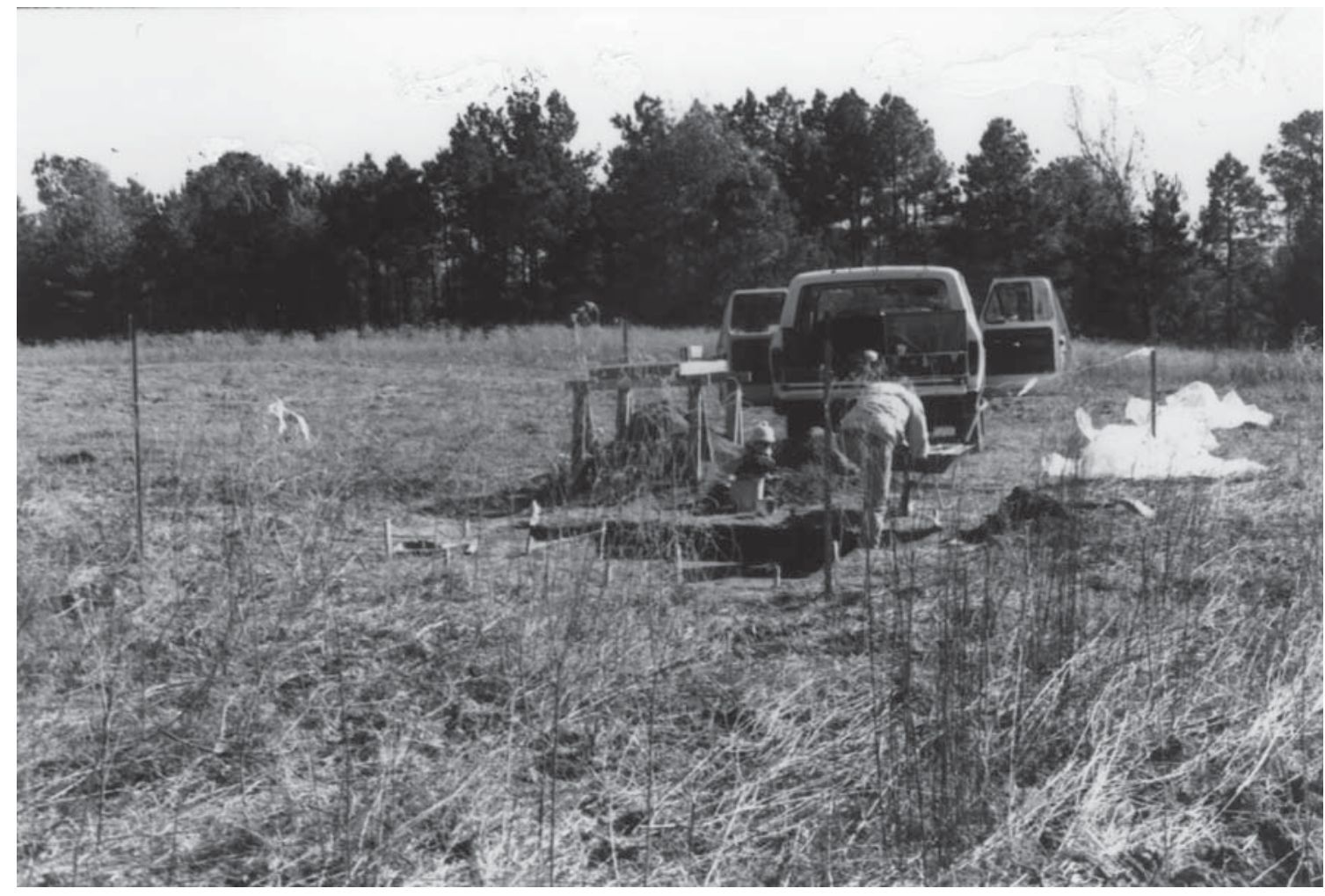

b

Figure 3. Views of the site: a, aerial photograph as viewed from the south; b, excavations in Area 1, November 1981. 


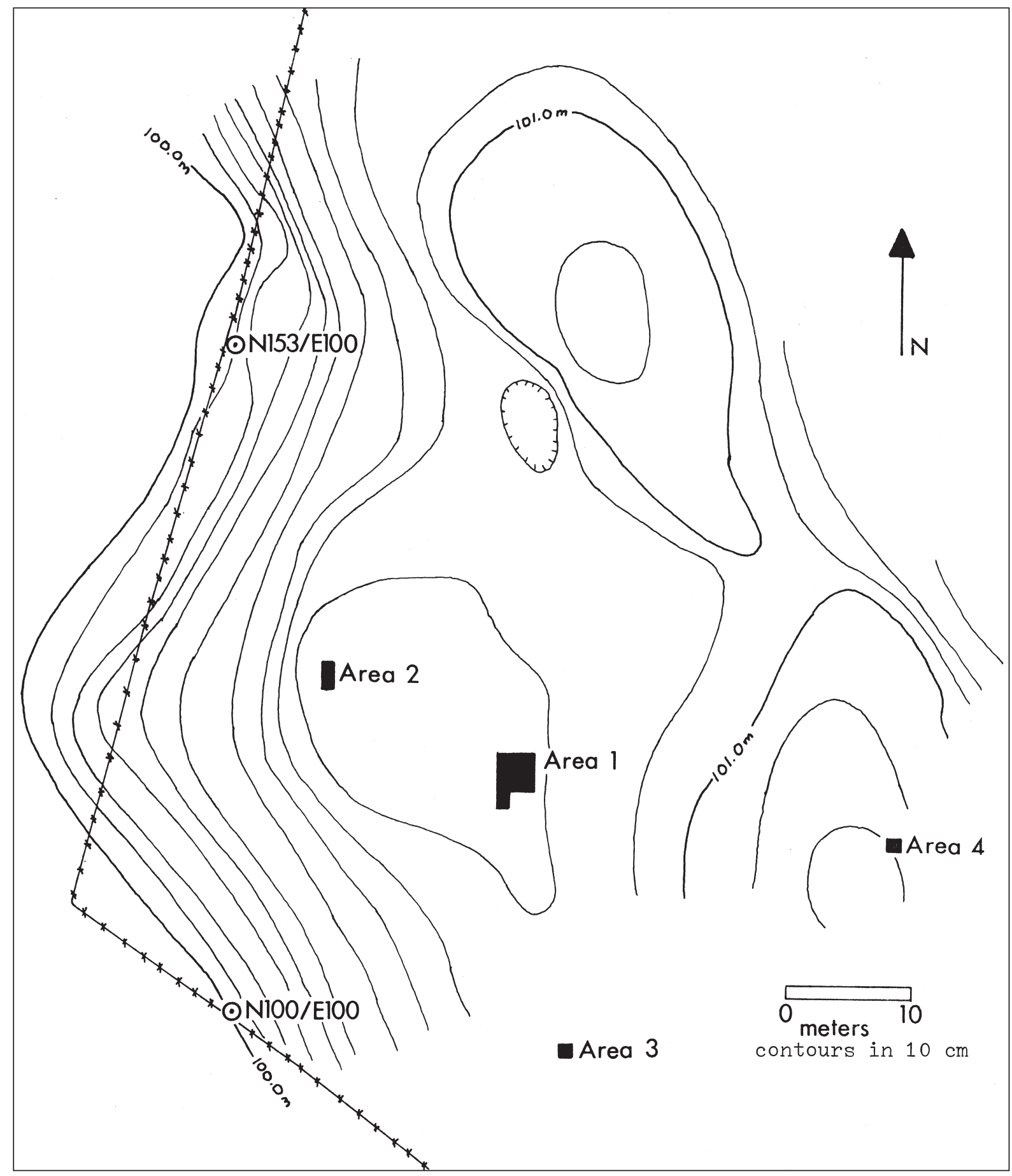

Figure 4. Topographic map of Areas 1-4 at the Jack Walton site.

drawn and photographs were taken (both black and white prints and color slides) at the end of excavating each $1 \times 1 \mathrm{~m}$ unit. Features were easily seen in Level II (near the top of the B-horizon) as dark discolorations on a background of light colored sandy clay.
All soil removed from each level was passed through a $1 / 4$-inch wire screen mesh. The recovered artifacts were bagged and labeled by unit and level. In the lab, the screened samples were first separated by flotation to collect any charcoal fragments and then by water washing to remove sand and silt so 


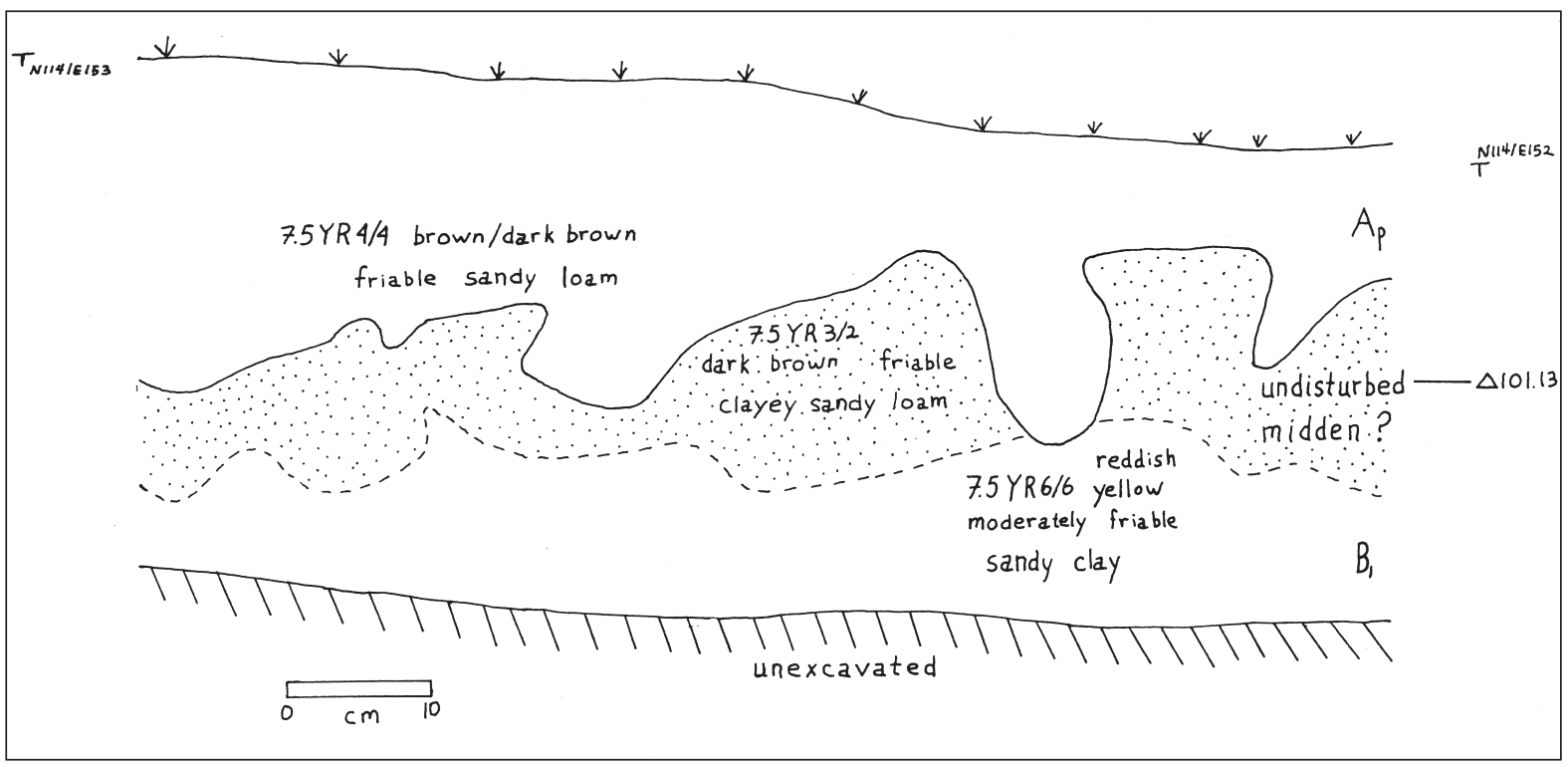

Figure 5. Profile of the south wall of N114/E152. The deep gouges in the upper surface of the undisturbed A-horizon midden were probably made during plowing.

concretions could be identified and discarded. The artifacts remaining were divided into broad groups (ceramics, chipped stone, lithic debitage, other lithics, faunal remains), underwent further cleaning, and were catalogued.

\section{EXCAVATIONS}

Excavations took place during 10 days in November 1981, four days in April 1982, and five days in July 1982. Fourteen $\mathrm{m}^{2}$ were opened to depths of $20-30 \mathrm{~cm}$ bs. Owing to our inexperience with the soil at the site, we designated many features during the initial phases of excavations, only to realize later that a vast majority of them were gopher and root stains (Figure 6a-b). Of the 23 features originally identified in the work, only two (Feature 1 and Feature 22) are clearly of aboriginal origin; four others (Feature 2, Feature 16, Feature 17, and Feature 20) are possibly of aboriginal origin. Fortunately we placed plastic sheeting at Level II over units where Features 16, 17, and 20 are located. This will offer us a chance to take a second look at these possible features during future excavations.

As will become apparent in the summary of the four excavated units, there exists a considerable variation between the areas in terms of the number of lithics, the number of sherds, the average weight of the sherds, the presence of bone and shell, ground stone tools, etc. Table 1 and Figure 7 summarize the total artifacts found in Areas 1-4.

\section{Area 1}

Area 1 is $10 \mathrm{~m}^{2}$ that was initially excavated as a $3 \times 3$ m unit with a southwest corner at N118/ E121 (elevation $100.91 \mathrm{~m}$ ); an additional $1 \times 1 \mathrm{~m}$ unit (N117/E121) was opened in order to examine Feature 22 more closely. The plow zone is a dark brown, friable, sandy loam with plentiful gravelsized concretions, typical for midden areas at the site. The top of the sterile B-horizon was at $17 \mathrm{~cm}$ bs on average. Some artifacts were recovered when Level III (20-30 cm bs) was excavated, but these appeared to be derived from the numerous gopher runs in this horizon.

A large number of sherds (103 per $10 \mathrm{~cm} \mathrm{level)}$ and lithic flakes (64 per $10 \mathrm{~cm}$ level) were collected in the screen. The average sherd was quite small (1.36 grams) and only $32 \%$ of the sherds were larger than $1.5 \mathrm{~cm}$ (see Table 1). A great diversity of surface decoration and tempering agents were found in the sherds. The sherds, however, from Area 1 as a group were typical of the overall sherd assemblage from the site, and no decorative pattern was found exclusively or predominantly here. A portion of a ceramic pipe bowl (with an inner shelf) was found in Area 1. Among the chipped stone artifacts from Area 1, there were 15 arrow points, 1 Palmillas (?) dart 

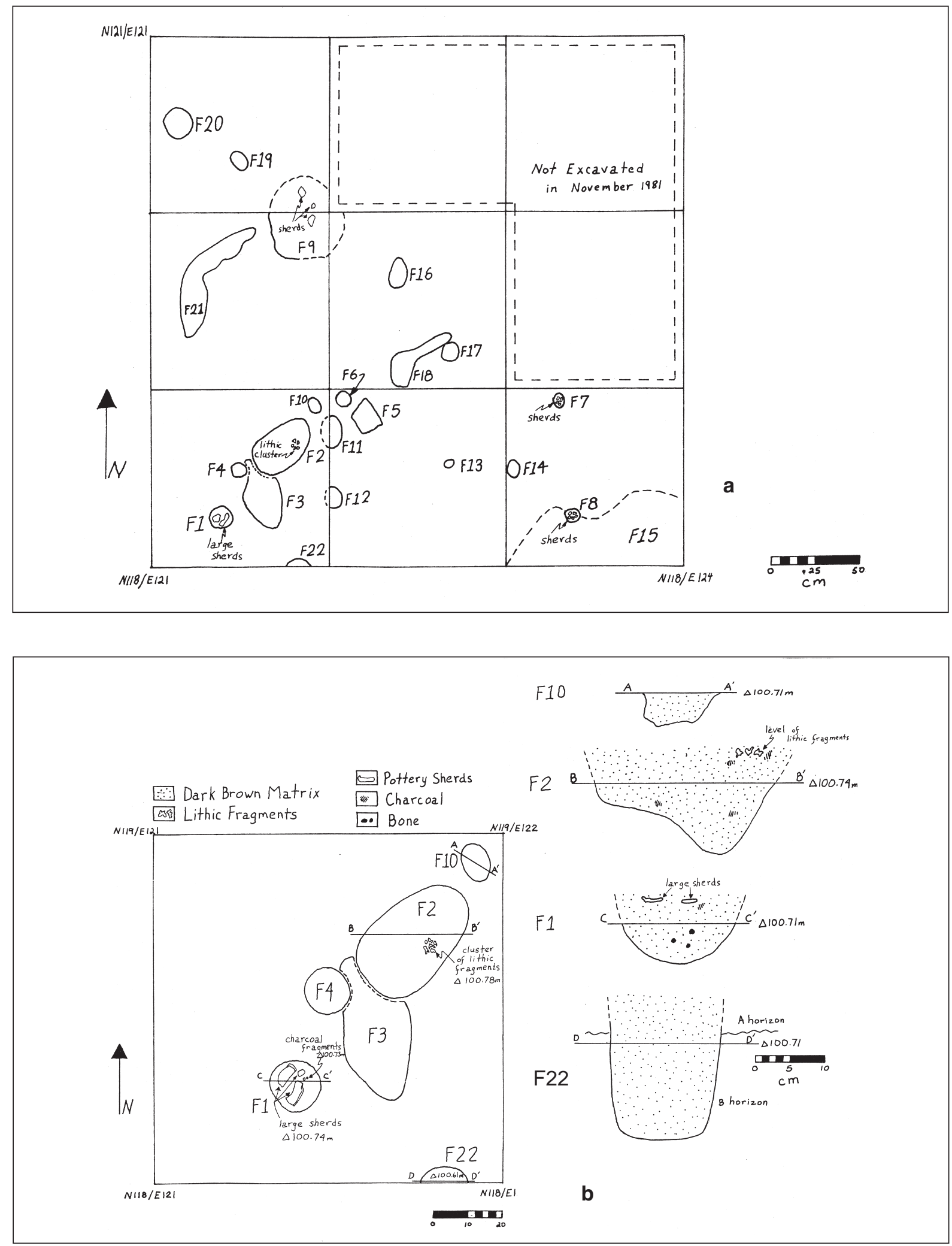

Figure 6. Features designated during excavations: a, Plan of N118/E121 ( 3 × $3 \mathrm{~m}$ unit) at level II (100.71 m in elevation). Only Feature 1 (trash pit) and Feature 22 (post hole) were later shown to be aboriginal. All the others are gopher runs or root stains. Feature 2 may have been a refuse pit, however. Features 16, 17, and 20 will be reexamined to determine their nature; b, Plan of N118/E121 (1 x 1 m unit) and cross-section of features. 
Table 1. Artifact Data by Areas.

\begin{tabular}{lrrrrr}
\hline & & & & & Surface \\
Artifact Data & Area 1 & Area 2 & Area 3 & Area 4 & Collection \\
\hline Ceramics $(<1.5 \mathrm{~cm})$ & 1437 & 273 & 16 & 49 & 56 \\
Ceramics $(>1.5 \mathrm{~cm})$ & 679 & 267 & 7 & 77 & 46 \\
Total No. of Ceramics & 2116 & 540 & 23 & 126 & 102 \\
\% of Ceramics $>1.5 \mathrm{~cm}$ & 32 & 49 & 30 & 61 & 45 \\
Average Wt. of Sherds (g) & 1.36 & 2.65 & 1.74 & 2.78 & - \\
No. of Sherds per 10 cm level & 101 & 135 & 12 & 42 & - \\
& 1282 & 348 & 37 & 77 & - \\
Total No. of Lithics & - & 6 & - & - & - \\
Ground stone tools & 61 & 87 & 19 & 26 & - \\
No. of Lithics per 10 cm level & 10 & 295 & - & 35 & - \\
Bone (g) & & & & & \\
\hline
\end{tabular}

\begin{tabular}{|c|c|c|c|c|}
\hline $\begin{array}{l}C=281 \\
\mathrm{~L}=203 \\
\mathrm{~B}=180 \mathrm{~g} \\
\mathrm{~S}=4 \text { pipe } \\
\text { shel1 }++\end{array}$ & $\begin{array}{l}C=174 \\
L=130 \\
B=0 \\
S=0\end{array}$ & $\begin{array}{l}C=189 \\
L=143 \\
B=0 \\
S=0\end{array}$ & $\begin{aligned} C=184 \\
L=135 \\
B=0 \\
S=0 \\
\quad \text { pipe }\end{aligned}$ & $\begin{array}{l}C=126 \\
L=77 \\
B=35 g \\
S=0\end{array}$ \\
\hline $\begin{array}{l}C=258 \\
L=145 \\
B=115 \mathrm{~g} \\
S=2 \\
\text { shell ++ }\end{array}$ & $\begin{array}{l}C=245 \\
L=124 \\
B=0 \\
S=0\end{array}$ & $\begin{array}{l}C=216 \\
L=95 \\
B=0 \\
S=0\end{array}$ & $\begin{array}{l}C=226 \\
L=156 \\
B=0 \\
S=0\end{array}$ & AREA 4 \\
\hline \multirow[t]{3}{*}{ AREA 2} & $\begin{array}{l}C=181 \\
L=79 \\
B=0 \\
S=0\end{array}$ & $\begin{array}{l}C=208 \\
L=126 \\
B=0 \\
S=0\end{array}$ & $\begin{array}{l}C=184 \\
L=90 \\
B=0 \\
S=0\end{array}$ & \\
\hline & $\begin{array}{l}C=309 \\
L=204 \\
B=1 \mathrm{~g} \\
S=0\end{array}$ & \multirow{2}{*}{\multicolumn{2}{|c|}{ AREA 1}} & $\begin{array}{l}C=23 \\
L=37 \\
B=0 \\
S=0\end{array}$ \\
\hline & & & & AREA 3 \\
\hline
\end{tabular}

Figure 7. Total number of artifacts found in each 1 x $1 \mathrm{~m}$ unit. $\mathrm{C}=$ number of ceramic artifacts; $\mathrm{L}=$ number of lithic artifacts, including points; $\mathrm{B}=$ amount of bone (in grams) recovered in the screen; $\mathrm{S}=$ number of ground stone artifacts and other large lithics. Additional notes indicate where pipes and shell were found.

point, one preform, a drill, and seven other small unidentified broken lithic fragments. Eleven of the arrow points are made of local cherts, and three others are made from petrified wood. The arrow point types include six Perdiz, three Alba, one Bassett, and one Friley; there are four untyped points. In contrast to Area 2, only $15 \mathrm{~m}$ to the west, no ground stone tools or large cobbles were found here. While there 
were occasional flecks of charcoal and bone noted in the soil, only a very small amount of these materials were collected from the screen.

Two cultural features were discovered in the Area 1 excavations. Feature 1 was found on the first day of excavations when two large pottery sherds in Level II of N118/E121 were encountered (Figure 8a; see also Figure $6 \mathrm{~b}$ ). One sherd is a large section near the base of a jar approximately $14 \mathrm{~cm}$ in greatest outside diameter, with diagonal coarse brushing paneled by parallel diagonal columns of fingernail punctations (Figure 9a). Vessel 2 is a large bowl roughly $35 \mathrm{~cm}$ in diameter with delicate cross-brushing on its surface (Figure 9b). Bits of charcoal and small bone fragments were quite numerous in the soil just beneath the sherds. Troweling at the base of Level II revealed a $16 \mathrm{~cm}$, round, dark brown discoloration in the lighter colored B-horizon (Figure 8b). On crosssectioning, Feature 1 appears to have been a small smooth-bottomed pit scooped out to a depth of 26 $\mathrm{cm}$ bs (see Figure 6b, profile C-C'). The residents of the site probably used the pit for discarding refuse.

Feature 22 is a post hole found while cleaning the south wall of N118/E121. This feature is a dark brown circular stain $15 \mathrm{~cm}$ in diameter that is most readily seen as it extends into the B-horizon. In cross-section, the sides of the post hole are straight; the rounded bottom is $36 \mathrm{~cm}$ bs (see Figure 6b, profile D-D').

As noted above, all of the other designated features have subsequently been shown to be fossil gopher runs or root stains, except Features 2, 16, 17, and 20 (see Figure 6). The latter three features are round dark soil discolorations at Level II and may be shown to be post holes in future examination. Feature 2 is problematic: it was originally designated on the basis of finding six large chert cores and flakes as well as one hematite conglomeration fragment in a large oval-shaped soil discoloration. Numerous bits of charcoal were also found. In profile the feature is basin-shaped and extends to $26 \mathrm{~cm}$ bs. Whether Feature 2 represents a refuse pit similar to Feature 1, or is an extensive gopher disturbed area, is unclear.

\section{Area 2}

A 1 x 2 m test pit (N126/E107 and N127/E107) was opened to Level II in order to study an area of especially dark soil and a high surface artifact content. The plow zone was a very dark brown, friable, sandy loam with a high organic material and charcoal content.
This unit differed from Area 1 in several ways. Both lithic (87 artifacts per level) and ceramic sherd (134 sherds per level) frequencies in Area 2 were considerably higher. Sherd size was larger $(2.65 \mathrm{~g}$ per sherd), and the percentage of sherds larger than $1.5 \mathrm{~cm}(49 \%)$ was also greater (see Table 1).

While the ceramic decorative groups were typical of the site, there were two notable findings. First, a curvilinear trailed and rocker stamped sherd typical of Troyville ceramics (Clarence H. Webb, 1983 personal communication) was found in Area 2. Second, the number of fingernail impressed sherds found here far exceeded what would have been expected by a random distribution of sherds over the excavated areas.

Chipped stone artifacts included one Perdiz point, one untyped arrow point, a drill, one scraper, and an atypical triangular chert point. In contrast to Area 1 where the majority of the lithic debitage was small flakes, a high percentage of the lithics in Area 2 were large cores, blades, and flakes, as well as chert cobble raw material. Four smoothed stones with a single shallow pit were also recovered; one unsmoothed sandstone fragment had a single large and deep pit. A ferruginous sandstone tool with a smoothed surface was also recovered in Area 2.

A moderate amount of charred wood and hardwood nut fragments were recovered from the screened sample by flotation. Six grams of shell remains were recovered in the form of mussel shell fragments and numerous small snails. The bones and teeth of deer and small game animals were very abundant (see Table 1). About $10 \%$ of the bones had been thermally altered, and several fish vertebrae were found.

With the large and diverse number of artifacts found there, Area 2 excavations seem to have been in a general purpose refuse midden. There is no indication, however, that the Caddo residents of the site attempted to modify the land surface (i.e., digging a pit for refuse disposal) to accommodate the accumulation of refuse. The sterile sandy clay B-horizon was consistently encountered by the time Level II was troweled, and no additional cultural features were identified after the troweling. Because of the small size of the Area 2 test pit, the areal extent of the midden is unknown.

\section{Area 3}

Area 3 is a $1 \times 1 \mathrm{~m}$ unit (N97/E126) $22 \mathrm{~m}$ south of Area 1 in a subtle surface depression. The Ahorizon was a light brown, friable, sandy loam 15 


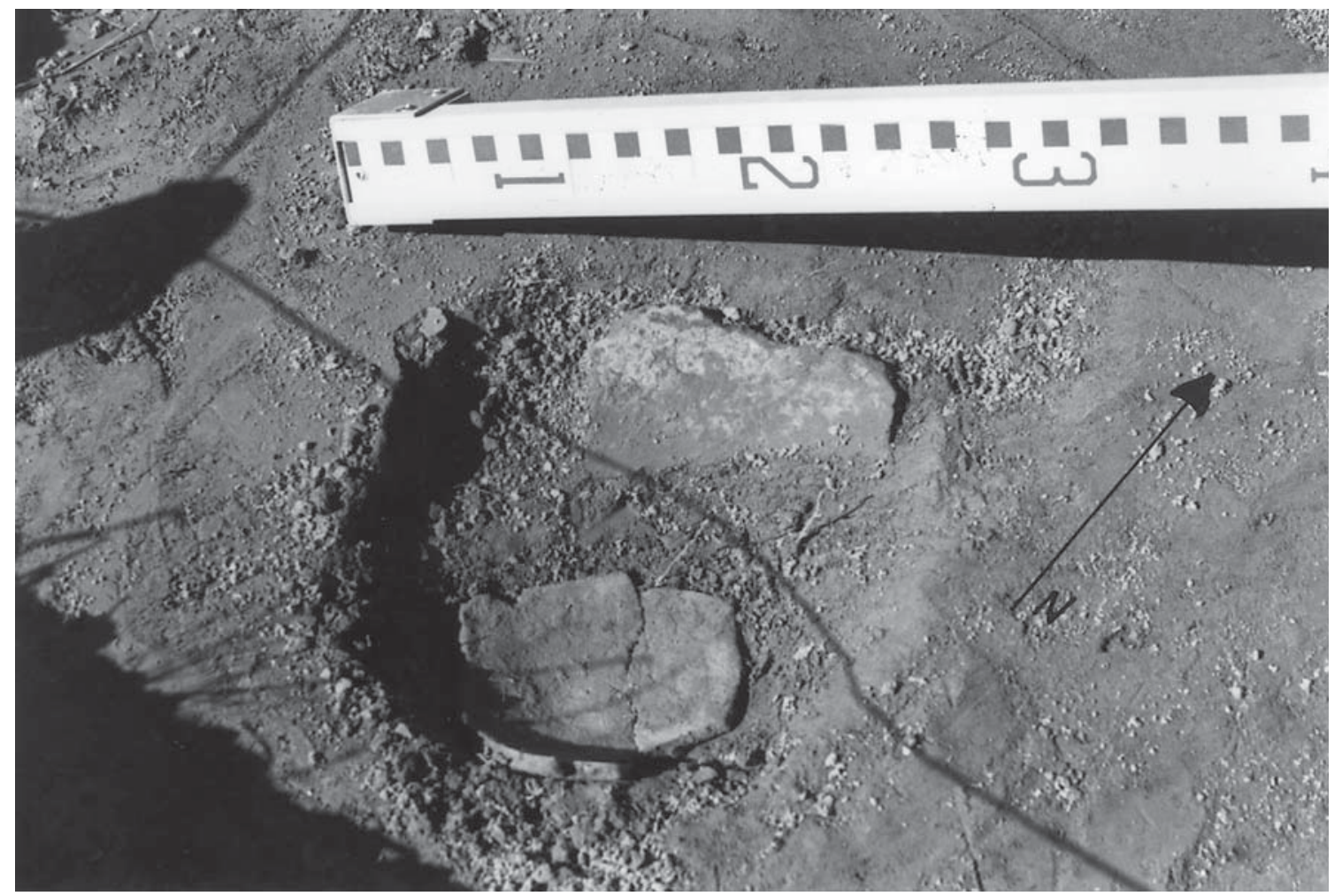

a

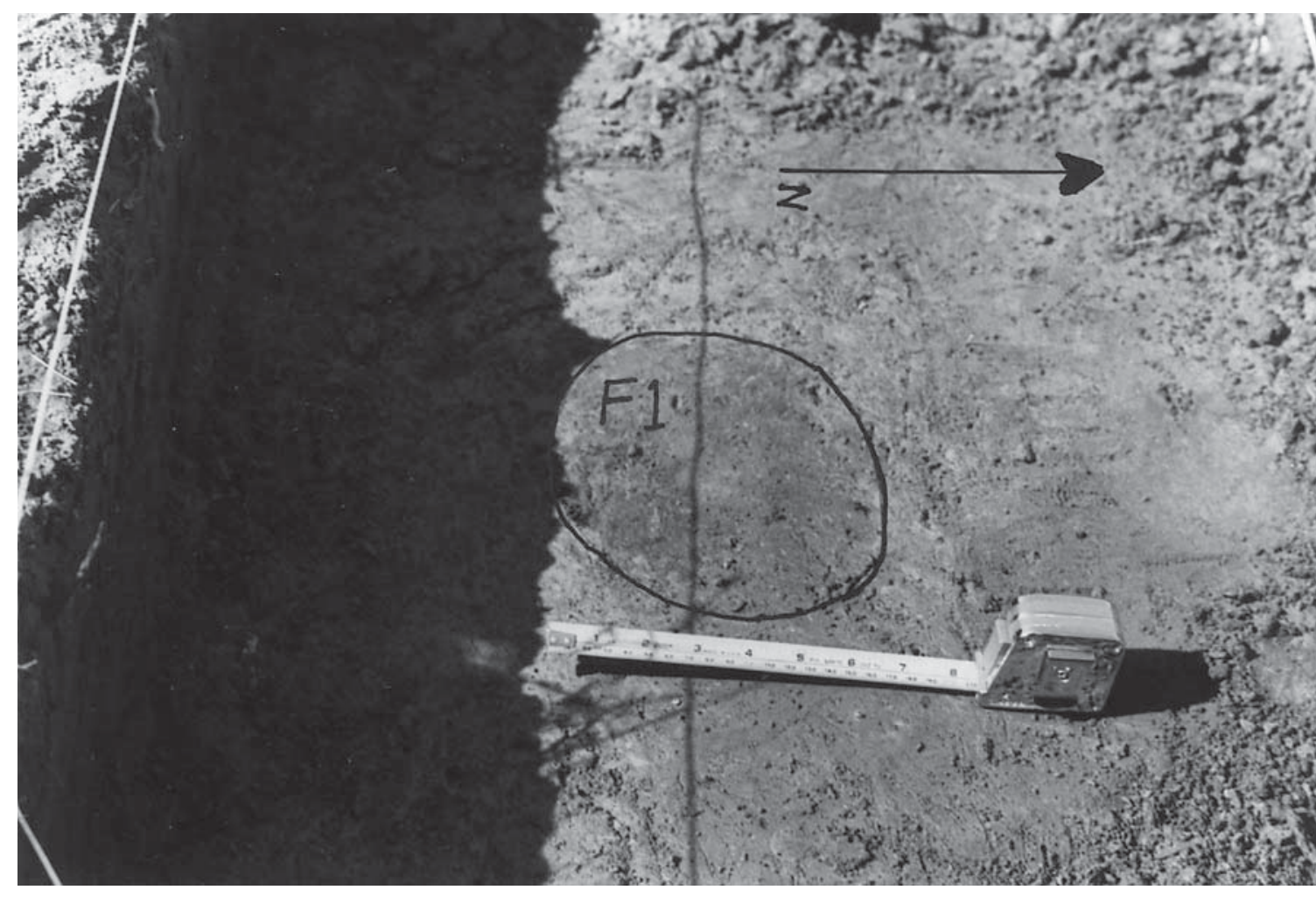

b

Figure 8. Feature 1: a, the discovery of two large sherds (Vessels 1 and 2); b, Feature 1 as seen at Level II beneath the two large sherds. 

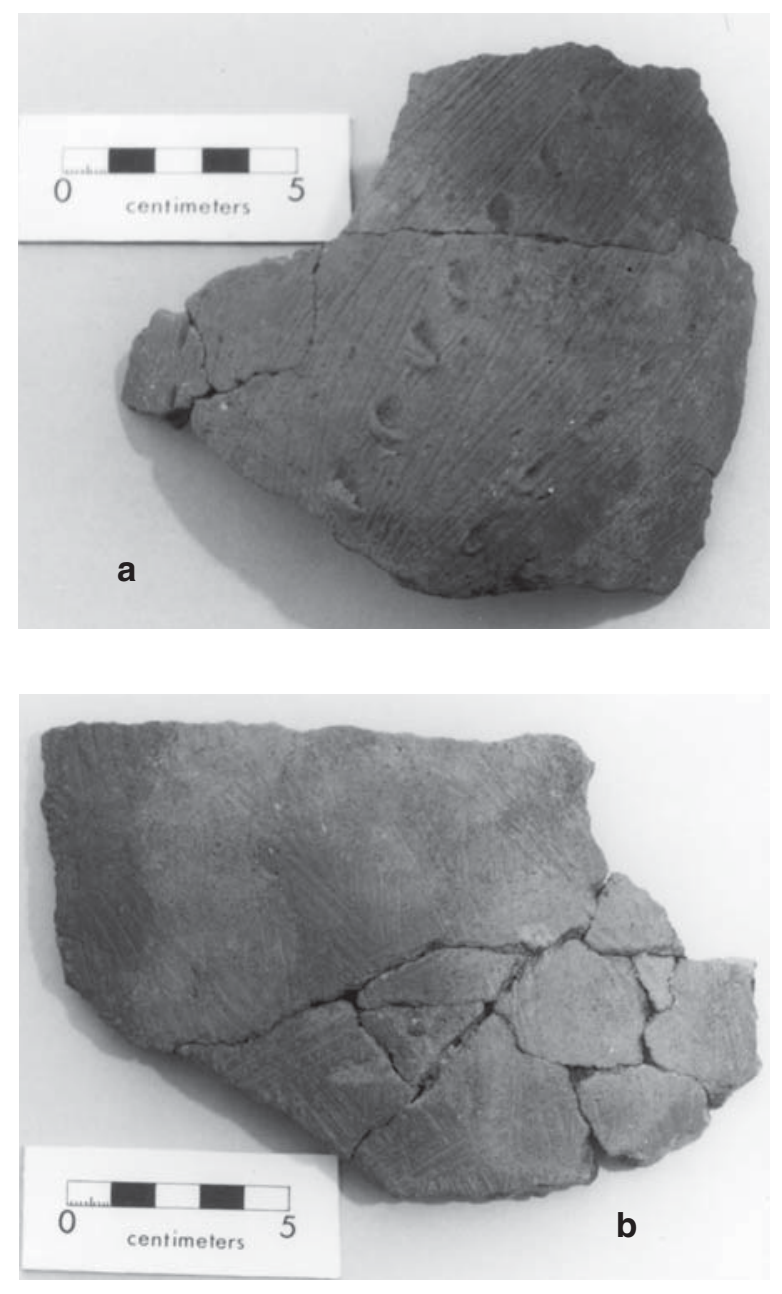

Figure 9. Vessel sections from Feature 1: a, Vessel 1; b, Vessel 2.

$\mathrm{cm}$ in thickness. Few ceramics (12 sherds per level) were recovered in the screening, and these were quite small (30\% of the sherds were larger than 1.5 $\mathrm{cm})$. One Friley arrow point was found in Area 3 along with 19 lithic debitage.

\section{Area 4}

About $30 \mathrm{~m}$ east of Area 1 is a $40 \mathrm{~cm}$ high rise on which there is a small concentrated midden deposit. A 1 x $1 \mathrm{~m}$ unit (N114/E152) was excavated in this area to examine the midden. The B-horizon in Area 4 was found at a greater depth $(22-30 \mathrm{~cm}$ bs) than in other site areas, which allowed for the distinction between the plow zone and the underlying undisturbed midden deposits (see Figure 5). The soil was speckled with charcoal and bone fragments
(35 g; about $50 \%$ of the bone had been thermally altered). No cultural features other than the midden itself was noted in Area 4.

While the frequency of artifacts in Area 4 was modest (31 sherds per level and 26 lithics per level) in comparison to the middens in Areas 1 and 2, average sherd size was larger ( $2.78 \mathrm{~g}$ per sherd and $62 \%$ of the sherds were larger than $1.5 \mathrm{~cm}$ ). Ceramic decorative styles were typical of the site as a whole. No arrow points were found, but two well-made Yarbrough dart points and the broken stem of a dart point were recovered from Area 4.

\section{CONCLUSIONS REGARDING AREA 1-4 EXCAVATIONS}

Although the foregoing excavation data is limited, some suggestions as to the prehistoric use of the four areas of the Jack Walton site are warranted. Areas 2 and 4 have significant similarities: both have very dark brown midden deposits with large amounts of animal bone and plentiful charcoal fragments. Additionally, in both areas ceramic sherds are much larger in size than they are in Areas 1 and 3. Since other determinants of sherd size (such as inherent ceramic breakage qualities, destruction by modern agricultural practices, differential washing and erosion of smaller sherds, etc.) appear to have been uniform over the site, it is possible to speculate that the larger sherds in Areas 2 and 4 are a product of some protection to broken pottery during original deposition from mechanical destruction (i.e., being repeatedly stepped on or otherwise crushed). Areas for the preparation and cooking of food or adjacent refuse piles could have offered such protection. Indeed, the artifact assemblage in both areas suggests such a use.

Area 1 is more difficult to understand. This portion of the site has a high density of lithic debitage and ceramic sherds, and the sherds are small in size on average. Area 1 is virtually devoid of bone, shell, charred wood and hardwood nuts, lithic raw material pieces, and ground stone tools. Refuse seems to have been handled by filling small, shallow pits (e.g., Features 1 and 2). Obviously, learning what association Feature 22 has to other post holes will be a great help in discerning the aboriginal use of the area. The most that can be said now is that Area 1 was likely used for residential activity.

The use of Area 3 by Archaic and Caddo inhabitants is uncertain. 
There are findings that may bear on the age of the components at the Jack Walton site. First, only one dart point was recovered in $2.8 \mathrm{~m}^{3}$ of screened deposits in Areas 1-3, while two Yarbrough points and the broken stem of a third dart point were found in $0.3 \mathrm{~m}^{3}$ of soil in Area 4. This tends to support a conclusion derived from surface collections that Archaic points are most frequently found in the eastern sections of the site, and away from the greatest concentrations of Caddo ceramics. Second, $63 \%$ of the sherds with fingernail impressions used as the only decoration $(n=17)$ were found in Area 2 , but only $25 \%$ of the total sherd assemblage was found there. Although the sample size is too small to be certain, this finding may suggest the use of the Area 2 midden by peoples who employed fingernail impressed ceramics at higher frequencies than temporally different (perhaps later) Caddo groups who utilized other midden areas.

\section{CERAMICS}

The focus of the ceramic analysis is to place the ceramic sherds $(n=2893)$ and other clay artifacts $(n=12)$ into broad descriptive groups based on surface decoration or form (Table 2). Generally, no attempt has been made to identify any particular group of sherds as belonging to recognized ceramic types.

Of all the collected sherds and other artifacts of clay, $63 \%(\mathrm{n}=1831)$ were smaller than $1.5 \mathrm{~cm}$ in their longest dimension and had no recognizable decoration. They were tabulated by unit and level, but received no further analysis. The remaining sherds and ceramic artifacts $(n=1074,37 \%$ of the total) were divided into seven broad groups: (a) undecorated $(\mathrm{n}=582,54.2 \%$ of the analyzed ceramics); (b) brushed as the only decoration $(\mathrm{n}=232,21.6 \%)$; (c) fingernail impressed and punctated $(\mathrm{n}=98,9.1 \%)$; (d) linear incised and engraved ( $\mathrm{n}=90,8.4 \%)$; (e) curvilinear and complex incised and engraved $(n=48$, $4.5 \%)$; (f) plain sandy paste $(\mathrm{n}=12,1.1 \%)$, and $(\mathrm{g})$ other clay artifacts $(\mathrm{n}=12,1.1 \%)$. These major groups were subsequently subdivided into more narrowly defined groups, which are described below.

\section{Plain Sandy Paste Sherds $(n=12,1.1 \%)$}

These plain body sherds are composed almost entirely of fine to medium grain sand; their eroded surfaces are gritty like sandstone, and sand easily rubs off them. About half of the sherds are dark brown to black in color, while the others are light tan on their outer surface. Mean thickness is $5.0 \pm 0.85 \mathrm{~mm}$ (4-7 $\mathrm{mm}$ range). These sherds fit Jelks (1965) description of Bear Creek Plain as well as the sandy paste sherds at the George C. Davis site (Story 1981).

An equal number of these sherds were found in both Areas 1 and 4, although Area 1 had nine times as many sherds overall. This finding may reflect the greater relative frequency of sandy paste sherds in the eastern portion of the site.

\section{Undecorated Sherds $(\mathrm{n}=\mathbf{5 8 2}, \mathbf{5 4 . 2 \%})$}

Most of these ceramic sherds are plain body sherds $(n=518)$. In order to get an impression of this large group, 50 sherds were randomly selected for further analysis. Microscopic paste analysis identified three primary paste-temper agents (Table 3). A medium to fine-grained quartz and hematitic sand (occasionally with large hematitic granules) was by far the most common agent ( $88 \%$ of the sherds), followed by grog $(74 \%)$ and bone $(50 \%)$. Usually when sand was present, it was in amounts of 20-25\% of the paste, although it some sherds sand formed as much as $40-60 \%$ of the paste. The most frequent tempering combination was sand-grog-bone (42\%). Sand and grog $(20 \%)$ and sand alone $(22 \%)$ were also common. Bone was never found as the sole tempering agent. A few flecks of charcoal were present in a few sherds. Shell temper has not been identified in the sherds from the Jack Walton site.

The surfaces of the plain body sherds were generally well smoothed, and in a few cases were polished. Interiors were usually dark brown to black, while outer surfaces ranged in color from brown to red to yellow. Mean body wall thickness is $5.8 \pm 1.14 \mathrm{~mm}$ (range, 4-9 mm).

Twenty-seven undecorated rim sherds are in the assemblage. The rims are vertical to gently everted, and most have straight sides; one rim is markedly thinned. Mean thickness is $4.8 \pm 0.9 \mathrm{~mm}$ (range, 3-7 $\mathrm{mm}$ ). The lip forms range from convex to flattened, and three rims have rolled out lips. Twenty-four plain shoulder sherds and 13 base sherds (average thickness, $8.8 \mathrm{~mm}$, range, $7-14 \mathrm{~mm}$ ) were also in the assemblage.

\section{Brushed Sherds $(n=232,21.6 \%$, Figure 10a-d $)$}

Brushing as the only decoration appears in nearly half of all the decorated sherds (see Table 2). This 
Table 2. Ceramic groups from the Jack Walton site.

\begin{tabular}{|c|c|c|}
\hline Ceramic Groups & $\mathrm{N}$ & $\%$ \\
\hline Ceramics smaller than $1.5 \mathrm{~cm}$ & 1831 & 63.0 \\
\hline Ceramics larger than $1.5 \mathrm{~cm}$ & 1074 & 37.0 \\
\hline Undecorated & 582 & $54.2 *$ \\
\hline Body & 518 & 48.2 \\
\hline Rim & 27 & 2.5 \\
\hline Base & 13 & 1.2 \\
\hline Shoulder & 24 & 2.2 \\
\hline Plain Sandy Paste & 12 & 1.1 \\
\hline Brushed as the only decoration & 232 & 21.6 \\
\hline Body & 228 & 21.2 \\
\hline Rim & 4 & 0.4 \\
\hline Punctated and Fingernail Impressed & 98 & 9.1 \\
\hline Fingernail Impressed & 17 & 1.6 \\
\hline Single poorly defined Punctation & 43 & 4.0 \\
\hline Punctated & 23 & 2.1 \\
\hline Punctated/Incised & 11 & 1.0 \\
\hline Punctated/Engraved & 1 & 0.1 \\
\hline Punctated/Brushed & 3 & 0.3 \\
\hline Linear & 90 & 8.4 \\
\hline Single Incised line & 21 & 2.0 \\
\hline Single Engraved line & 24 & 2.2 \\
\hline Parallel Incised lines & 26 & 2.4 \\
\hline Parallel Engraved lines & 19 & 1.8 \\
\hline Curvilinear and Complex & 48 & 4.5 \\
\hline Incised & 16 & 1.6 \\
\hline Engraved & 31 & 2.9 \\
\hline Trailed/Rocker Stamped & 1 & 0.1 \\
\hline Other Artifacts of clay & 12 & 1.1 \\
\hline Pipe sherds & 2 & 0.2 \\
\hline Cylinders or coils & 5 & 0.5 \\
\hline Burned clay & 1 & 0.1 \\
\hline Appliqué node & 1 & 0.1 \\
\hline Atypical clay object & 2 & 0.2 \\
\hline Historic Ceramic & 1 & 0.1 \\
\hline
\end{tabular}

*percentage of the ceramics larger than $1.5 \mathrm{~cm}$ 
Table 3. Temper and paste analysis of a sample $(n=50)$ of plain sherds.

\begin{tabular}{lcc}
\hline Paste-Temper Categories & No. & $\%$ \\
\hline Sand (20-30\% of the sherd) & 4 & 8 \\
Sand (40-60\% of the sherd) & 7 & 14 \\
Sand (20\% of the sherd), bone-grog temper & 19 & 38 \\
Sand (50\% of the sherd), bone-grog temper & 2 & 4 \\
Sand (20\% of the sherd), bone temper & 2 & 4 \\
Sand (20\% of the sherd), grog temper & 10 & 20 \\
& & 4 \\
Grog-bone temper & 2 & 8 \\
Grog temper & 4 & 88 \\
Summary of paste categories & & 74 \\
Sherds with 20-60\% sand in the paste & 44 & 50 \\
Sherds with grog temper & 37 & \\
Sherds with bone temper & 25 & \\
\end{tabular}

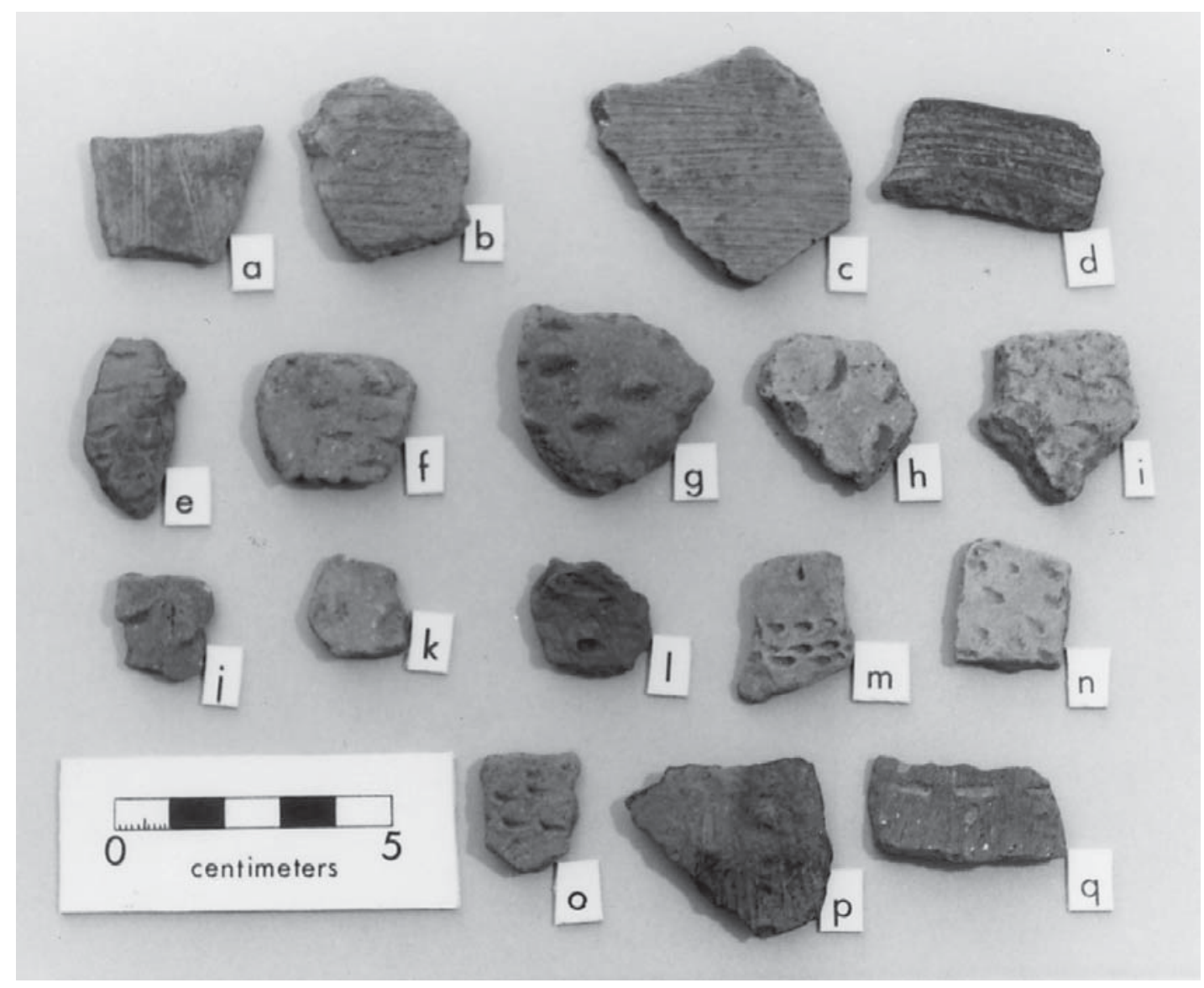

Figure 10. Brushed and punctated sherds: a-c, brushed; d, brushed rim; e-i, fingernail impressed; j-k, pinched; 1-o, punctated; p-q, punctated/brushed. 
group is comprised of four rim and 228 body sherds. The brushing varies widely from delicate wispy brushes to very coarse deep brush marks that seem to grade into parallel trailed and incised designs.

Of the sherds in which vessel axis could be determined, $35 \%$ had vertical brushing, 35\% had horizontal brushing, 16\% had diagonal brushing, and $14 \%$ had cross brushing. The four rim sherds (all with horizontal brushing) were gently everted with convex and slightly rolled lips. Colors of the brushed sherds were typically light to dark brown. Mean thickness of the sherds was $5.3 \pm 1.2 \mathrm{~mm}$ (range, 4-8 mm). Brushed sherds seem to be evenly distributed across the excavated areas.

\section{Fingernail Impressed Sherds $(n=17,1.6 \%$, Figure 10e-k)}

This group of sherds were decorated with the use of fingernail impressions while the clay was still plastic; this includes three pinched sherds (see Figure $10 \mathrm{j}-\mathrm{k}$ ). There is considerable diversity in the form of the punctations. Some have crisp margins; five sherds have evidence that the clay was intentionally raised on one side of the fingernail impression; another sherd has a circular impression where the fingernail was used to gouge out a depression. Patterns ranged from neat columns of impressions to haphazard arrangements.

The sherds ranged from very dark gray to light brown in color. Mean thickness was $5.9 \pm 1.45 \mathrm{~mm}$ (range, 4-9 mm). As mentioned above, 63\% of the fingernail impressed sherds came from Area 2. No fingernail impressed sherds were found in Area 4 on the eastern side of the site.

\section{Punctated Sherds $(\mathrm{n}=81,7.5 \%$, Figures 10i-q and 11a-f)}

This group was subdivided into sherds with single or poorly defined punctations $(n=43)$, sherds with multiple punctations $(\mathrm{n}=23)$, punctated/ incised line $(\mathrm{n}=11)$, punctated/engraved line $(\mathrm{n}=1)$, and punctated/brushed $(n=3)$ (see Table 2). The punctations in this group are very heterogeneous: pin point, triangular, irregular gouges, elongated instrument punctated, etc. The general impression is that the decoration was not very carefully done,

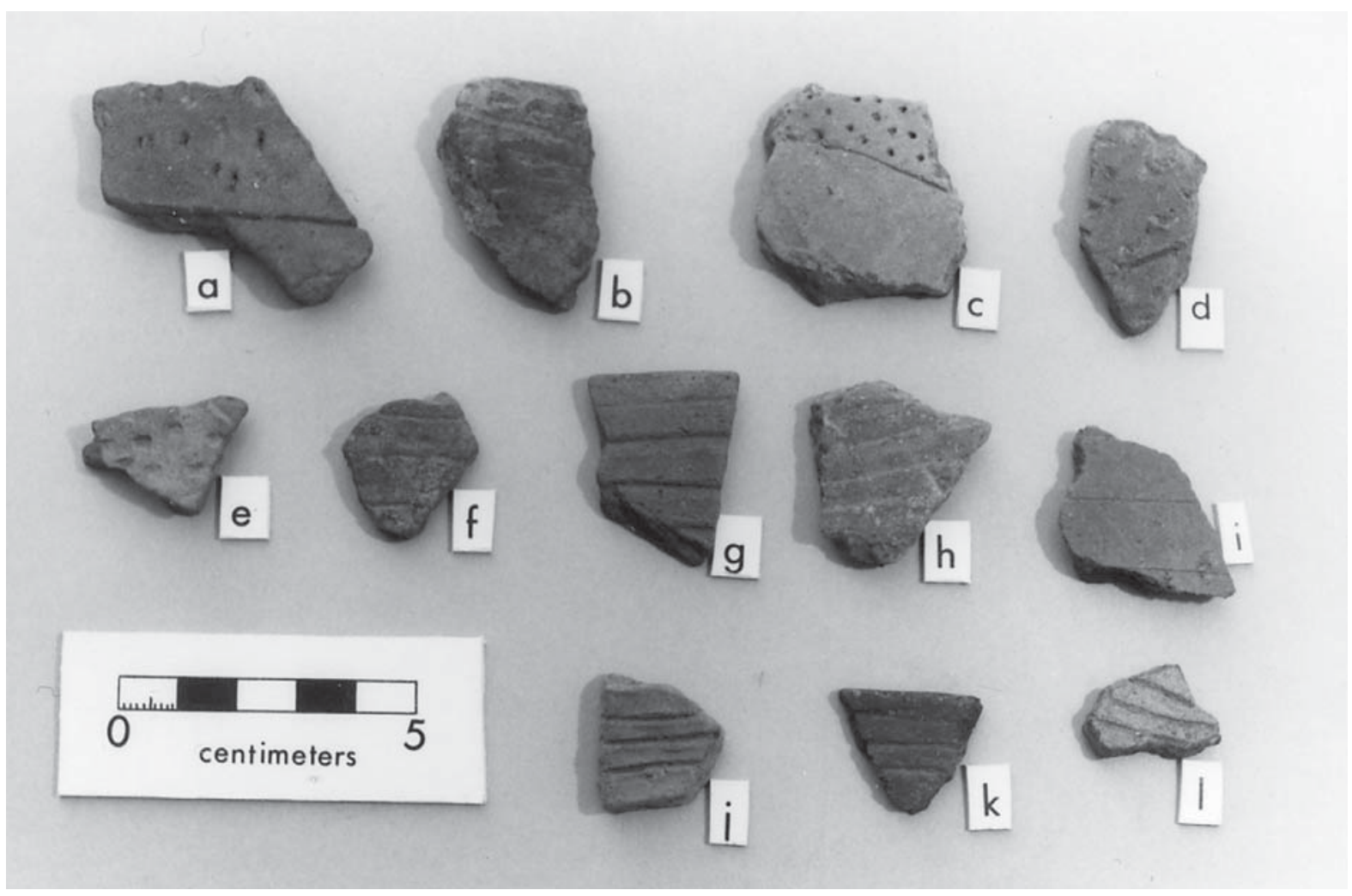

Figure 11. Punctated and Incised sherds: a-f, punctated/incised lines; g-l, incised lines. 
and fields of punctations are not symmetrically arranged. In the punctated/incised sherds, the punctations are zoned on one side of an incised line. One rim sherd had a horizontal row of dot punctations; the rim was slightly flared with a convex rounded lip.

The punctated sherds are typically dark brown to tan in color. Mean thickness is $6.3 \pm 1.34 \mathrm{~mm}$ (range, 5-9 mm). Punctated sherds are apparently evenly distributed across the site.

\section{Linear (Incised and Engraved) Decorated Sherds $(\mathrm{n}=90,8.4 \%$, Figure 11g-l)}

Although difficult to distinguish in some sherds, about half of the sherds in this group have incised lines and the remainder have engraved lines. Four groups have been defined: single incised line $(n=21)$; single engraved line $(n=24)$; parallel incised lines $(n=26)$; and parallel engraved lines (see Table 2). The incised lines vary from very narrow and shallow to deeply trailed. The lines are $4.7 \mathrm{~mm}$ apart on average (range, 2-12 $\mathrm{mm}$ ). The sherds with engraved lines looked similar to those with incised lines, and they had similar spacing of lines $(5.5 \mathrm{~mm}$ on average, range, 3-10 $\mathrm{mm}$ ). Both incised and engraved sherds had comparable surface treatment, and none were polished. Colors in the linear sherd group varied from dark brown to light brown, with some reds. No concentration of these sherds was noted in any one area of the site.

\section{Curvilinear and Complex (Incised and Engraved) Decorated Sherds $(n=47,4.4 \%$, Figure 12a-h)}

This group includes 31 engraved and 16 incised sherds. No one sherd is large enough to display the overall decorative pattern, however, several sherds may have a scroll design; these sherds have a crosshatched pattern. One sherd from the neck of a bottle may have an engraved "brick wall" design (Figure 12h). Several of the incised sherds tend to grade into a cross-brushed design.

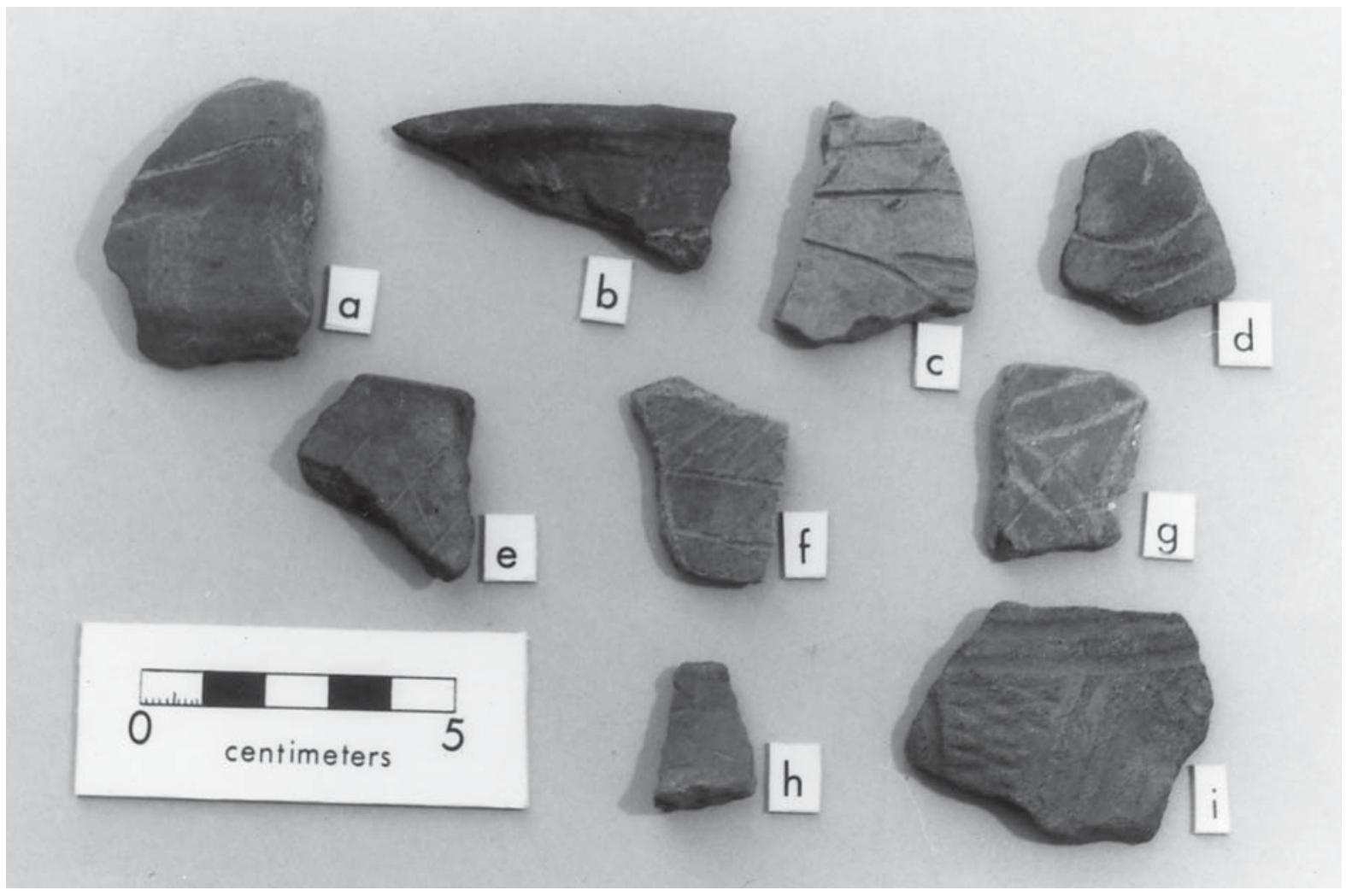

Figure 12. Curvilinear and complex decorated sherds: a-h, curvilinear and complex; i, curvilinear trailed and rocker stamped (possible Troyville Stamped). 


\section{Curvilinear Trailed/Rocker Stamped Sherd $(\mathrm{n}=1,0.1 \%$, Figures $12 \mathrm{i}$ and 13$)$}

One sherd was found in Area 2 with deep curvilinear trailing ( $3 \mathrm{~mm}$ wide line) with zoned rocker stamping. This sherd is likely from a Troyville Stamped vessel. The sherd is $5 \mathrm{~mm}$ thick with a dark brown exterior and black core and interior surface. A medium quartz-hematitic sand forms $70 \%$ of the sherd paste, and is the only tempering agent.

\section{Pipes $(n=2,0.2 \%$, Figure 14a-b)}

Two pipe sherds were found at the Jack Walton site during the excavations. One in Area 1 is the front half of a thick pipe bowl with a $3 \mathrm{~mm}$ wide inner shelf. The walls of the bowl are 6-7 mm thick. Its exterior surface is U-shaped and has been lightly polished. The other pipe sherd was from Area 2. It is a thickwalled $(6-10 \mathrm{~mm})$ pipe bowl with a $3 \mathrm{~mm}$ inner shelf; it is more crudely made than the first pipe. The second pipe sherd has been smoothed but not polished.
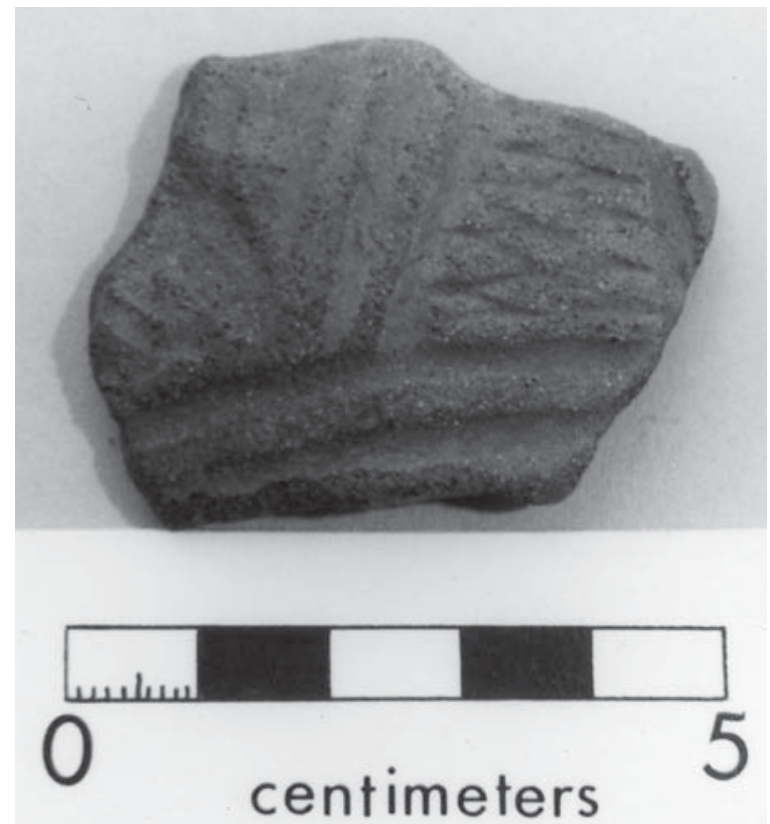

Figure 13. Close up of Curvilinear trailed/rocker stamped sherd.

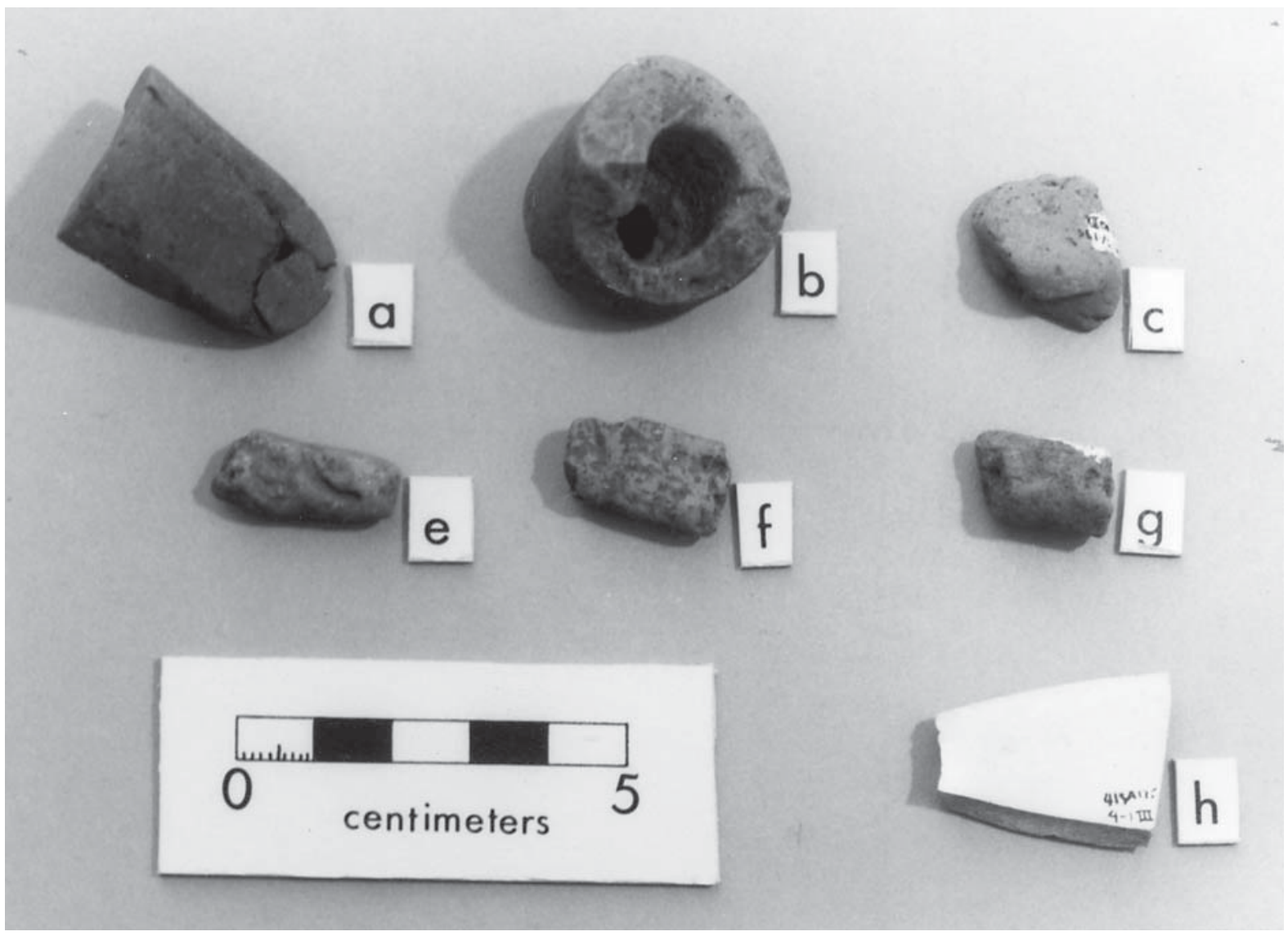

Figure 14. Pipes and other clay artifacts: a-b, pipes; c, appliqued node; e-g, coils; h, modern historic ceramic sherd. 


\section{Other Clay Artifacts $(n=10,0.9 \%$, Figure 14c-h $)$}

Five coils of fired clay were recovered in the excavations, four from Area 2 and one from Area 1. Other clay artifacts include an amorphous chunk of burned clay (Area 2), a broken off appliqued node, two atypical clay objects, and a piece of historic ceramic pottery (Area 4).

\section{LITHICS}

All but 63 of the 1744 lithic artifacts found at the Jack Walton site were classified as lithic debitage or raw material. These were usually small chips and flakes, but blades, cores, and unmodified lithic raw material was also recovered, especially in Area 2. Most of the chipped lithics were composed of tan to red local creek chert, and to a lesser extent local petrified wood. However, the sample does include light-colored Central Texas cherts and other exogenous cherts.
At present, no systematic analysis of the lithic debitage has been conducted except to document the location where the artifacts were found. In general, lithic concentrations tend to co-vary with ceramics: high numbers of artifacts in Area 1 (61 per level) and Area 2 (87 per level), but lower frequencies in Area 3 (19 per level) and Area 4 (26 per level) (see Table 1). Area 3 is the only area where more lithics than ceramics were found.

The 39 identifiable chipped stone artifacts and 12 ground stone tools are described below. Sixteen fragments of arrow points, dart points, and manufacture failures were also found, but have not been analyzed.

\section{Arrow points}

The largest group of identified arrow points (Suhm and Jelks 1962) were Perdiz points $(n=7$, Figure $15 \mathrm{a}-\mathrm{g})$. These were all recovered in the western part of the site (six from Area 1 and one from Area 2). Three other points are probably

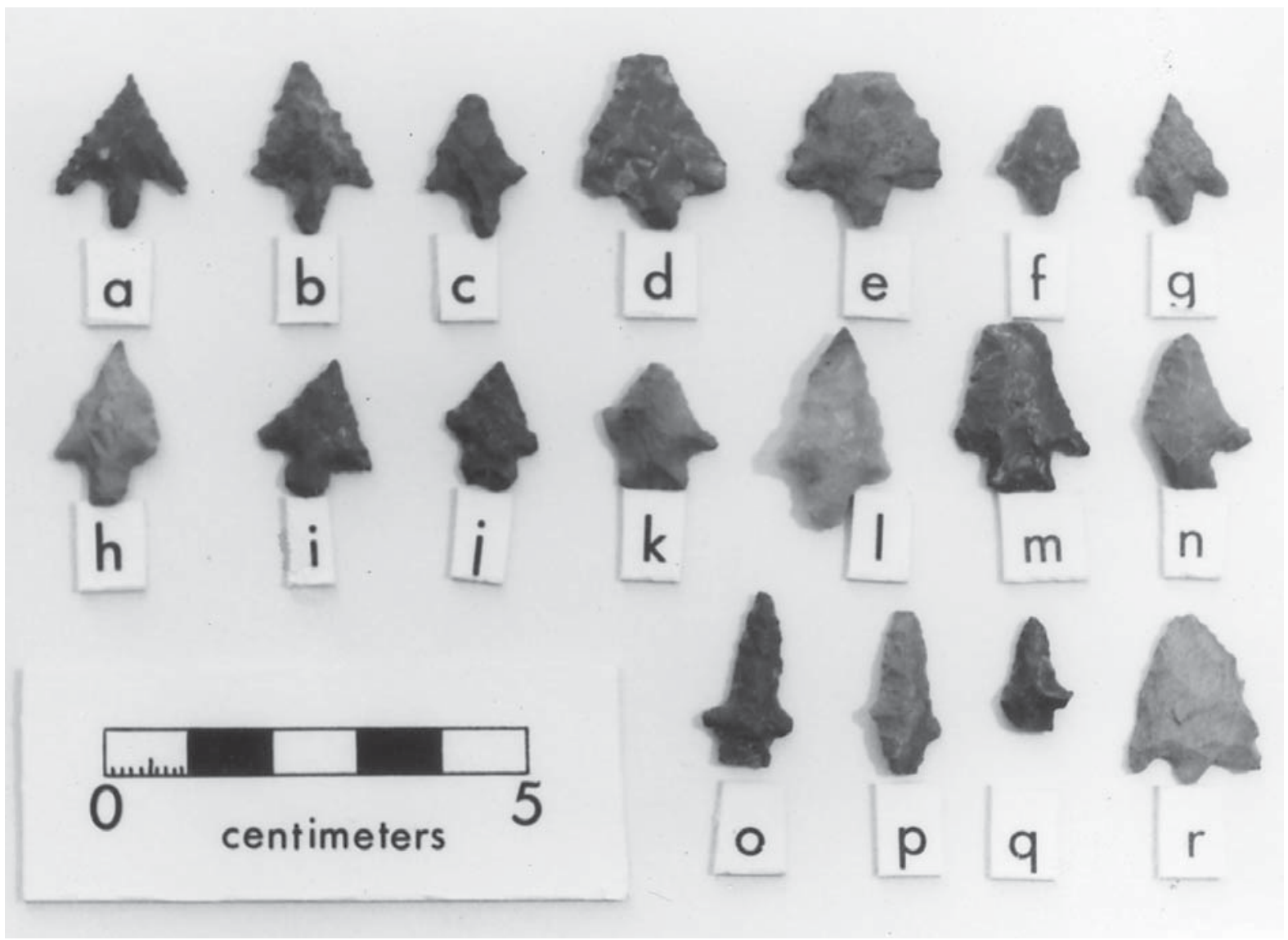

Figure 15. Arrow points: a-g, Perdiz; h-1, Alba; m-n, Colbert; o-q, Friley; r, Bassett. 
Perdiz, but are untyped because they have broken stems. The Perdiz points vary from red to tan and gray in color; two were formed of petrified wood, and the others were made on local cherts. Workmanship varies from poor to excellent. Some have delicately serrated edges. The blades are triangular with straight edges, and shoulders are straight to markedly barbed. Stems (average length is $4.7 \mathrm{~mm}$ ) are quite contracted.

The group of five Alba points are somewhat heterogeneous, but all of them share a triangular blade with basically triangular stems (see Figure 15h-l). Edges are straight to very slightly recurved. Shoulders are straight to mildly barbed. Two points (see Figure 15j-k) have wide stems (7-9 $\mathrm{mm}$ ); another has a slightly bulbous stem (see Figure 15i).

Three Friley points were also recovered (see Figure $15 \mathrm{o}-\mathrm{q})$. All were small with narrow $(5 \mathrm{~mm})$ recurved blades and laterally projecting barbs. Two broken arrow points are tentatively identified as Colbert (Webb 1963) on the basis of blades that resemble Alba points but with expanding stems produced by corner-notching (see Figure 15m-n). One Bassett point was found (see Figure 15r). Five arrow points are untyped because of broken stems.

\section{Dart points}

By far the most striking of the dart points is one with a triangular blade, a blunt tip, and a strongly concave base (Figure 16f). This point was found in an Area 2 surface collection. It measures $50 \mathrm{~mm}$ in length and is $25 \mathrm{~mm}$ wide at the base. The composition is a brown non-local chert; microscopic examination suggests a chert formed by siliceous replacement of a fossiliferous limestone. Webb (1983 personal communication) conjectured that the point was made by late Paleoindian peoples.

Two well-made Yarbrough points were found in Area 4 (see Figure 16h-i). They are both formed from petrified wood and have similar dimensions (55 mm in length and $20 \mathrm{~mm}$ wide at the shoulders). One possible Palmillas (see Figure 16g) has a short

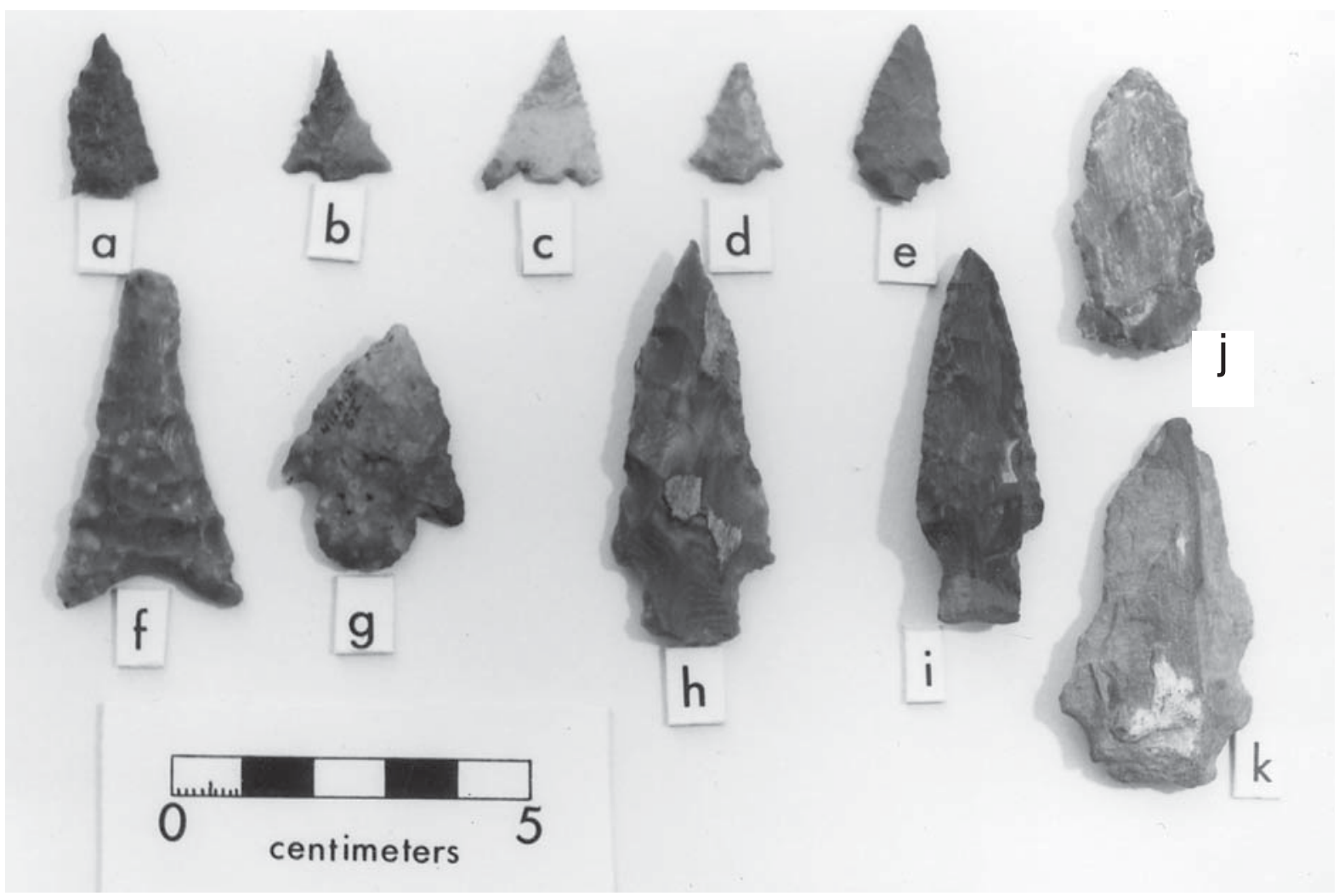

Figure 16. Projectile points: a-e, untyped arrow points; f, untyped point of possible Paleoindian origin; g, Palmillas; h-i, Yarbrough; j-k, untyped dart points. 


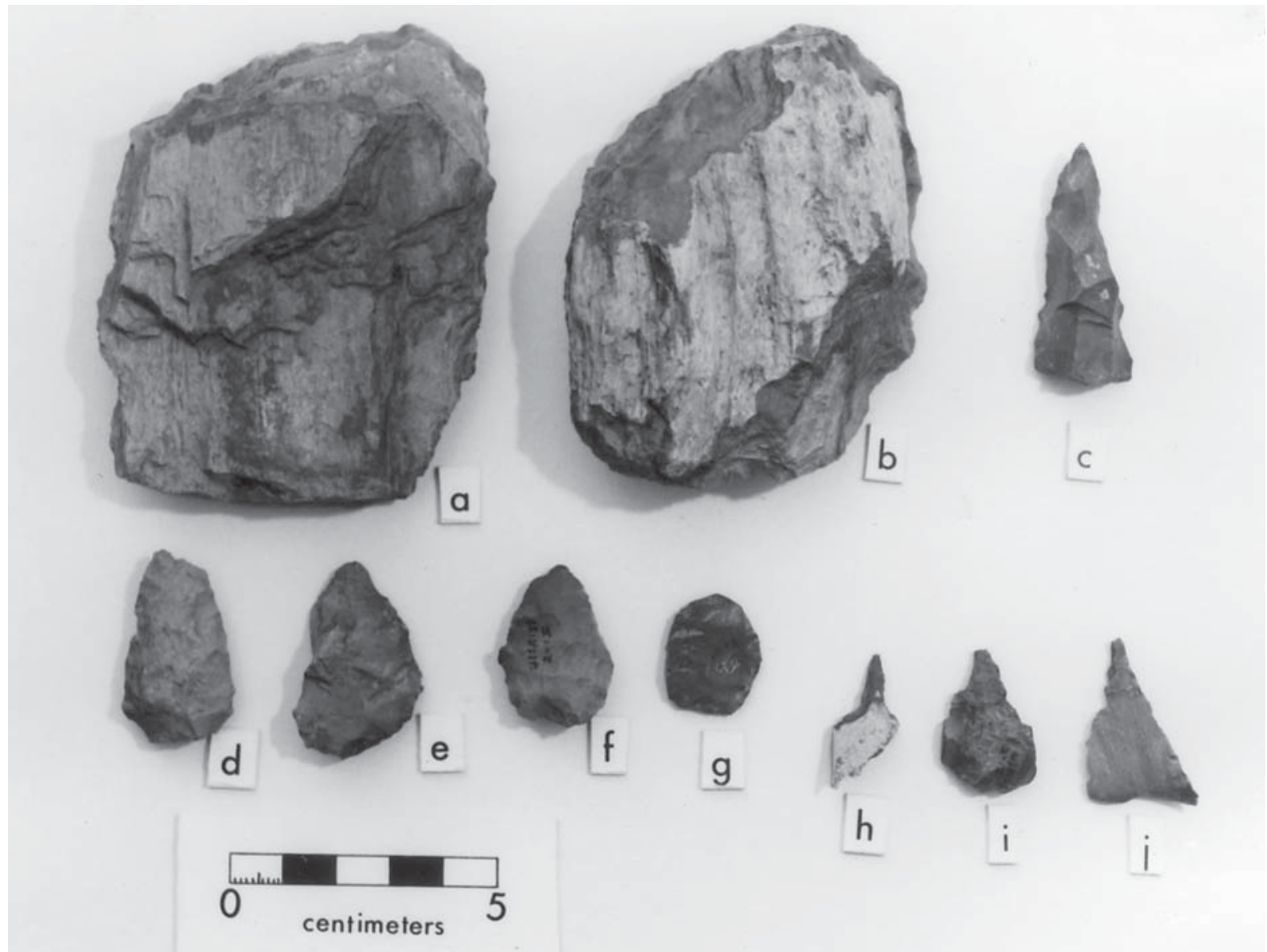

Figure 17. Other chipped stone artifacts: a-b, choppers; c, atypical triangular point; d, preform; e-g, scrapers; h-i, perforators.

triangular blade with slightly convex edges and barbed shoulders. The stem is bulbous and is not quite $33 \%$ of the entire length. Two crudely formed petrified wood dart points (see Figure 16j-k) were found in surface collections in the far eastern sector of the site.

\section{Other Chipped Stone Artifacts $(\mathrm{n}=10)$}

Three perforators were recovered at the Jack Walton site, each with a distinctive morphology. One has a long $(11 \mathrm{~mm})$, narrow $(4 \mathrm{~mm})$ bit on a largely unworked base (Figure 17h). This perforator, made of a local red chert, fits the description of Jelks' (1965) Form III drill. A second perforator (akin to Jelks' Form II) is a bifacially worked petrified wood artifact with a triangular bit and an ovoid base (Figure 17i). The third perforator is a wedgeshaped fragment of petrified wood $30 \mathrm{~mm}$ in length and lightly chipped on the lateral edges.
One tan chert preform was recovered from Area 1 (see Figure 17d). Three generally oval-shaped scrapers (see Figure e-g) were also collected from the site. All three were formed of dark red local chert and were bifacially chipped. An unusual red chert point triangular in cross-section was found in Area 2 (see Figure 17c). It is unclear if this is a fragment of a larger artifact or a preform, core, or another kind of chipped stone artifact. Two large choppers of petrified wood (see Figure 17a-b) were found in surface collections.

\section{Ground stone Tools $(\mathrm{n}=12$, Figures 18 and 19)}

Six cobble-sized stones with most sides smoothed by abrasion were found, four in Area 2 and two in surface collections. All had a single, shallow, centrally located pit on a flat, smoothed surface (Figure 18b-c). Three of these pitted stones were 


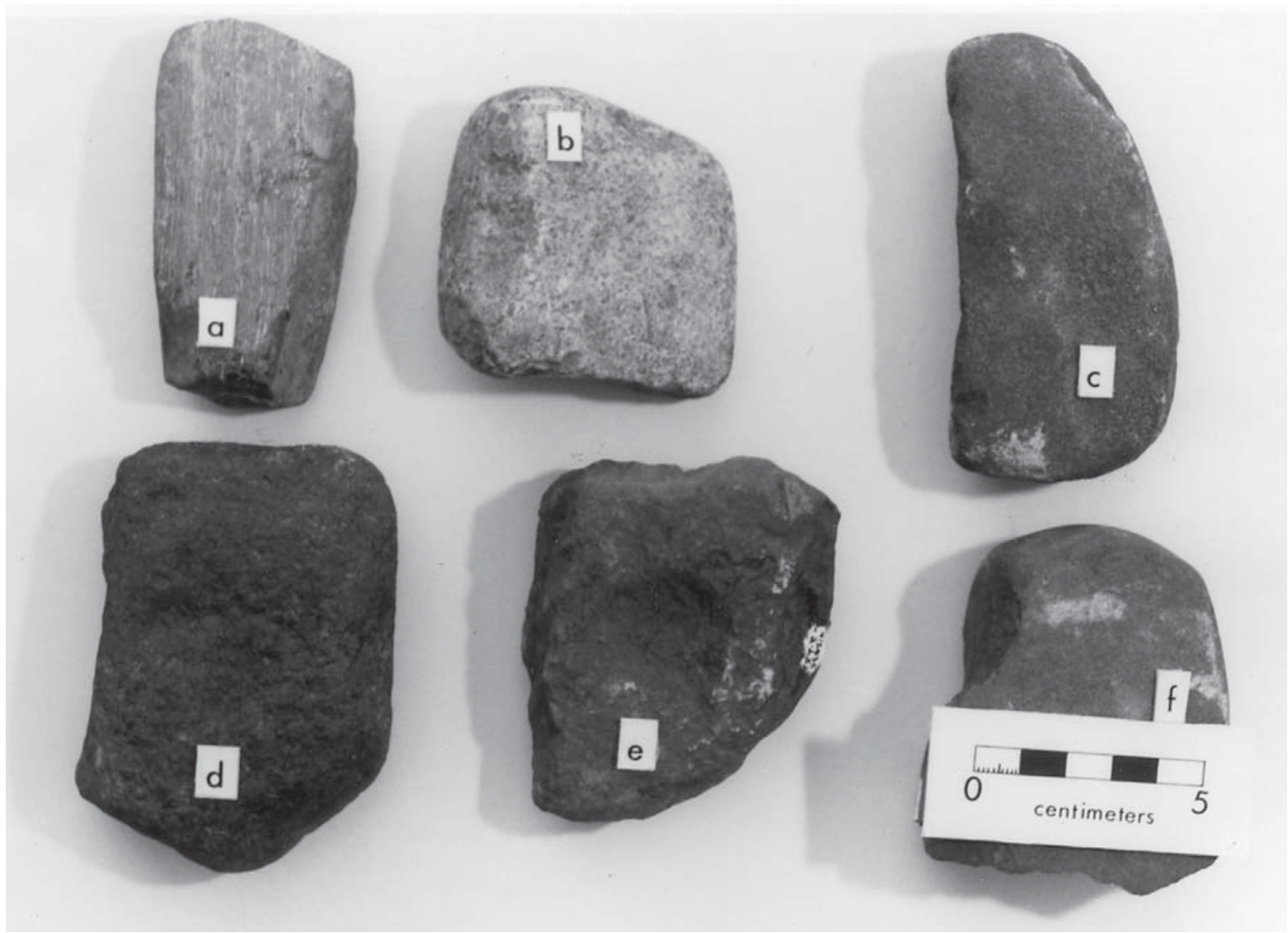

Figure 18. Ground stone tools: a, petrified wood hammerstone; b-c, smoothed pitted stones; d, smoothed/pecked pitted stone; e, rough surface pitted stone; f, mano (?) fragment.

composed of ferruginous sandstone, two of quartzite (Catahoula Formation?), and one of limestone. Two of the ferruginous sandstone artifacts also have evidence of pecking (Figure 18d).

A second category of pitted stones consisted of two large lithic artifacts with a rough surface and one large, deep pit (see Figure 18e). One stone was composed of ferruginous sandstone; the other was made of a large slab of fossiliferous marly sandstone from the Weches Formation (Figure 19a).

One each of the following artifacts were recovered from the Jack Walton site: (a) a concave abraded stone composed of ferruginous sandstone, found in the surface collections, most likely a milling slab (see Figure 19b); (b) a broken mano (?) from Area 2 (see Figure 18f) made of ferruginous siltstone; an oblong abraded cobble of marly glauconite from a surface collection (see Figure 19c); and (d) a petrified palm wood hammerstone found in a surface collection (see Figure 18a).

\section{CONCLUSIONS}

The modest amount of archaeological investigations at the Jack Walton site in 1981 and 1982 does not support detailed interpretations. Therefore, the emphasis of this article has been a descriptive one. Nevertheless, a few conclusions about the cultural components represented at the site can be made.

Excavation data suggests several occupations of this high bluff on Attoyac Bayou: (1) one triangular dart point (see Figure 16f) may represent the work of a late Paleoindian group; (2) a Middle/Late Archaic component is evidenced by a number of dart points, including Yarbrough and Palmillas types and crudely-made petrified wood points. These points and the lithic debitage related to their manufacture are scattered over a large area, especially in the eastern portions of the site; (3) a curvilinear trailed/ rocker stamped sherd tempered with local sand indicates the presence of Troyville peoples at the 


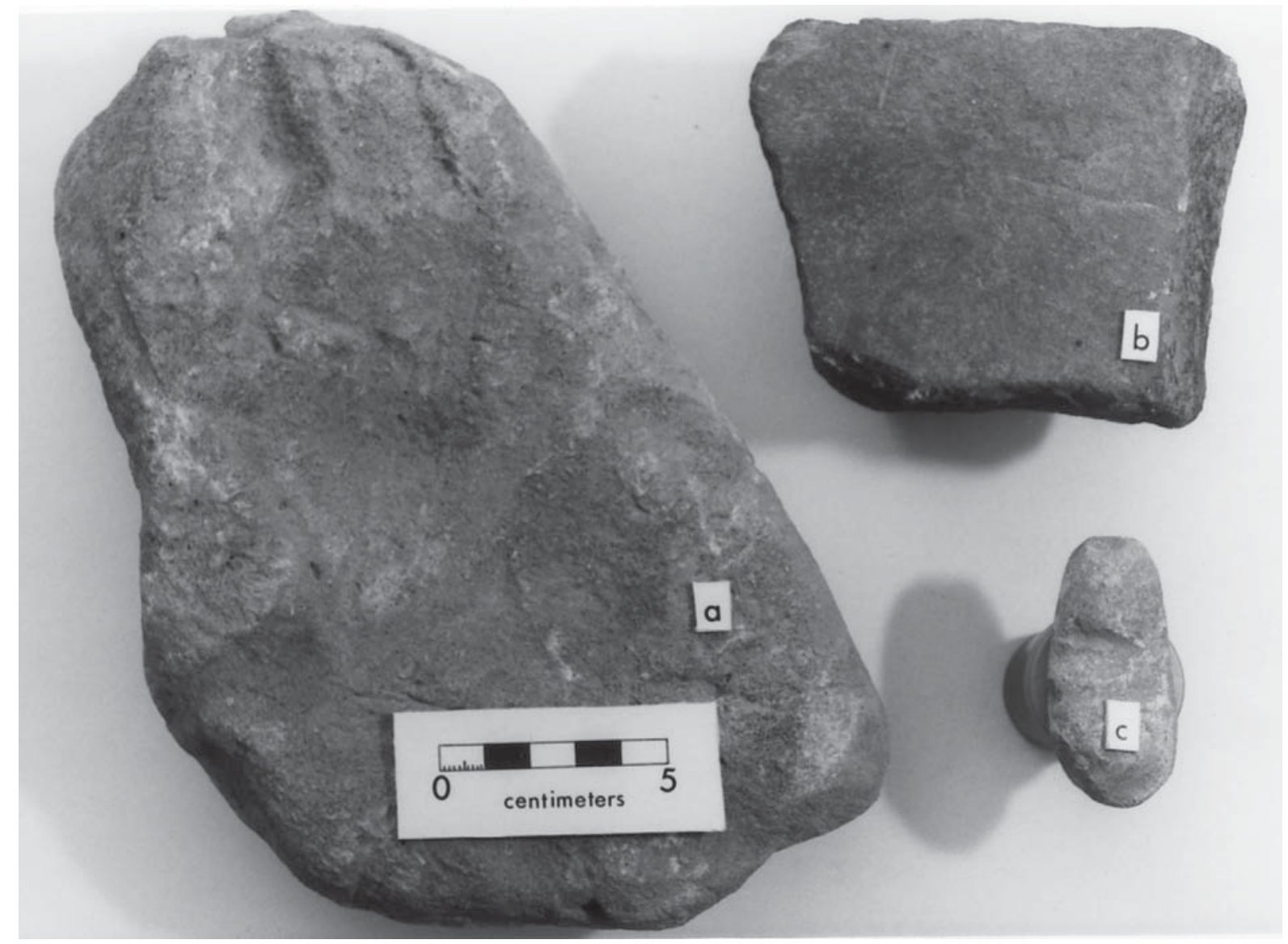

Figure 19. Other ground stone tools: a, pitted stone in slab of Weches glauconitic sandstone; b, fragment of milling stone; c, atypical smoothed stone.

site, although I cannot rule out that this sherd came from a trade vessel; (4) a component of the Early Ceramic or Woodland period is recognized on the basis of several sandy paste sherds; these sherds may be distributed in areas similar to the Middle/ Late Archaic points; and (5) the Caddo component is certainly the most prominent one at the Walton site, and is characterized by a large ceramic assemblage and arrow points such as Perdiz, Alba, and Bassett.

The crucial question is whether or not there are several Caddo components here. The fingernail impressed sherds (concentrated in Area 2) and the punctated/incised sherds are similar to some Early Caddo (Alto phase) types. On the other hand, the large number of brushed sherds and the overall similarity to the artifact assemblages from a few Angelina Focus sites (e.g., Walter Bell, see Jelks 1965; see also Corbin et al. 1978) suggests a Middle/ Late Caddo period component. Future work emphasizing the differential intrasite distribution of lithic and ceramic types, radiocarbon dating, and careful comparison to nearby sites such as Washington Square (41NA49) in Nacogdoches and the McElroy site a few kilometers to the northeast of Jack Walton, will help delineate the Caddo cultural components present at the Jack Walton site.

Jack Walton is a rich archaeological site bearing evidence of occupation by a wide range of native inhabitants. It clearly provides exciting possibilities for continued investigations. 


\section{REFERENCES CITED}

Corbin, J. E., J. Studer, and L. Numi

1978 The Chayah Site. Papers in Anthropology No. 1. Stephen F. Austin State University, Nacogdoches.

Jelks, E. B.

1965 The Archeology of McGee Bend Reservoir, Texas. Ph.D. dissertation, Department of Anthropology, The University of Texas at Austin.

Middlebrook, T.

1983 The Jack Walton Site (41SA135), San Augustine County, Texas: A Preliminary Report on the 19811982 Excavations. MS on file with author.
Story, D. A. (editor)

1981 Archeological Investigations at the George C. Davis Site, Cherokee County, Texas: Summers of 1979 and 1980. Occasional Papers No. 1. Texas Archeological Research Laboratory, The University of Texas at Austin.

Suhm, D. A. and E. B. Jelks (editors)

1962 Handbook of Texas Archeology: Type Descriptions. Special Publication No. 1, Texas Archeological Society, and Bulletin No. 4, Texas Memorial Museum, Austin.

Webb, C. H.

1963 The Smithport Landing Site: An Alto Focus Component in De Soto Parish, Louisiana. Bulletin of the Texas Archeological Society 34:143-187. 